https://doi.org/10.5194/cp-2021-103

Preprint. Discussion started: 11 August 2021

(c) Author(s) 2021. CC BY 4.0 License.

\title{
Abrupt climate changes and the astronomical theory
}

Denis-Didier Rousseau ${ }^{1,2}$, Witold Bagniewski ${ }^{3}$, and Michael Ghil ${ }^{3,4}$

${ }^{1}$ Geosciences Montpellier, University Montpellier, CNRS, Montpellier, France

${ }^{2}$ Lamont-Doherty Earth Observatory, Columbia University, New York, 10964, USA

$5{ }^{3}$ Laboratoire de Météorologie Dynamique (Institut Pierre Simon Laplace and CNRS), Ecole Normale Supérieure and PSL University, Paris, France

${ }^{4}$ Department of Atmospheric and Oceanic Sciences, University of California, Los Angeles, CA 90095, USA

Correspondence to Denis-Didier Rousseau (denis-didier.rousseau@umontpellier.fr) 
Abstract

Abrupt climate changes constitute a relatively new field of research, which addresses variations occurring in a relatively short time interval of tens to a hundred years. Such time scales do not correspond to the tens or hundreds of thousands of years that the astronomical theory of climate addresses. The latter theory involves

15 parameters that are external to the climate system and whose multi-periodic variations are reliably known and almost constant for a large extent of Earth history. Abrupt changes, conversely, appear to involve fast processes that are internal to the climate system; these processes varied considerably during the past $2.6 \mathrm{Myr}$, and yielded more irregular fluctuations. In this paper, we re-examine the main climate variations determined from the U1308 North Atlantic marine record, which yields a detailed calving history of the Northern

20 Hemisphere ice sheets over the past 3.2 Myr. The magnitude and periodicity of the ice-rafted debris (IRD) events observed in the U1308 record allow one to determine the timing of several abrupt climate changes, the larger ones corresponding to the massive iceberg discharges labeled Heinrich events (HEs). In parallel, abrupt warmings, called Dansgaard-Oeschger (DO) events, have been identified in the Greenland records of the last glaciation cycle. Combining the HE and DO observations, we study a complex mechanism that may lead to the observed millennial-scale variability corresponding to the abrupt climate changes of last 0.9 Myr. This mechanism relies on amended Bond cycles, which group DO events and the associated Greenland stadials into a trend of increased cooling, with IRD events embedded into every stadial, the latest of these being an HE. These Bond cycles may have occurred during the last $0.9 \mathrm{Ma}$ when Northern Hemisphere ice sheets reached their maximum extent and volume, thus becoming a major player in this time interval's climate dynamics. Since

30 the waxing and waning of ice sheets during the Quaternary period are orbitally paced, we conclude that the abrupt climate changes observed during the Mid and Upper Pleistocene are therewith indirectly linked to the astronomical theory of climate.

Key words:

Astronomical theory of climate, abrupt changes, Milankovitch, Dansgaard-Oeschger events, Bond cycles,

Heinrich events, ice rafted debris, ice sheets, intrinsic climate variability 
Well-dated geological data indicate that the Earth experienced orbitally paced climate changes since at least the late Precambrian - 1.4 billion years ago during the Proterozoic Eon (Benn et al., 2015; Zhang et al., 2015; Hoffman et al., 2017; Meyers and Malinverno, 2018), and all along the Phanerozoic (Lisiecki and Raymo, 2005; Liebrand et al., 2011; Miller et al., 2011; Kent et al., 2017, 2018; Olsen et al., 2019; Drury et al., 2020; Westerhold et al., 2020). These changes reflect the variations in the Earth's axis of rotation - precession and tilt, and in the geometry of the Earth's orbit around the sun - eccentricity, driven by gravitational interactions within the Solar system (Berger, 1977; Laskar et al., 2011). These variations affect the distribution of insolation at the top of the atmosphere, forcing latitudinal and seasonal climate changes with periodicities of tens or hundreds of thousands of years. Although well acknowledged presently in the climate community, this mechanism took a long journey to reach such general acceptance (Imbrie \& Imbrie, 1986).

In the 1840s, while visiting Scotland, Agassiz (1842) attributed erratic boulders noticed in the local landscape to

50 former ice age glaciers in the area, recalling his former observations in Switzerland (Agassiz, 1838). Meanwhile, Adhémar (1842) proposed that glaciations, like those inferred by Agassiz from field observations, occurred every 22,000 years, due to the Earth's evolving on an elliptic orbit with its rotation axis tilted with respect to the orbital plane. Adhémar also concluded that, as the Southern Hemisphere receives less solar radiation per year than the Northern Hemisphere (Adhemar was relying on the number of the nights at the

55 boreal pole versus the number of nights at the austral pole), this contributed to keep temperatures cold enough to allow ice sheets to build up.

Five decades later, Croll (1890) presented his theory of the ice ages being driven by the changing distance between the Earth and the Sun as measured on December 21, which is due to the eccentricity of the Earth's orbit and the precession of the equinoxes. He used formulae for orbital variations developed by Le Verrier

60 (1858) and also stated that, above a particular threshold, Northern Hemisphere winters would trigger an ice age, while below another threshold, an ice age would develop in the Southern Hemisphere. According to Croll's theory, it is the slowly evolving eccentricity of the Earth's orbit that is the key driver, with glaciations occurring only when eccentricity is high. He concluded, therefore, that eccentricity can impact the annual amount of heat received from the sun and also leads to differences in seasonal temperatures.

65 Parallel to these physical calculations, observations of frontal moraines in the Alpine valleys led to the identification of numerous glacial events in the past. Considering the geometry and position of the terrace systems resulting from these moraines in Alpine valleys, Penck and Brückner (1909) identified four main glaciations, determined from ice advances in the Alpine foreland: Günz, Mindel, Riss and Würm. This sequence became the paleoclimate framework for many decades, until the development of marine and ice coring 70 programs.

Thirty years after Croll, Milankovitch $(1920,1941)$, inspired by his exchanges with W. Köppen and A. Wegener, provided a crucial step in advancing the theory that major past climate changes had an astronomical origin resulting from the interaction between the eccentricity of the Earth's orbit around the sun, the precession of the equinoxes, and the tilt of the Earth's rotation axis. This theory, often given today his name, implies a fairly

75 regular, multi-thousand-year variability. Based on this crucial idea and on using the recent orbital calculations of Pilgrim (1904), among others, Milankovitch was able to estimate temperatures and insolation at various latitudes at the top of the atmosphere and to follow their variations through time. Among the results of these 
estimates, he found that the summer insolation at $65^{\circ} \mathrm{N}$ is best correlated with glacial-interglacial transitions, as determined by Penck and Brückner's (1909) study of Alpine glaciations.

80 Milankovitch's astronomical theory of climate was severely criticized by contemporary physicists and rejected by most Quaternary geologists as isotopic $C^{14}$ dating threw the Günz-Mindel-Riss-Würm classification out the window (e.g., Flint, 1971, and references therein). Interest in this theory was restored, however, as the pace of Quaternary climate changes - defined now by $\delta^{18} \mathrm{O}$ records from benthic foraminifera (Emiliani, 1955) - was connected on a much sounder basis with orbital variations in the seminal paper of Hays et al. (1976). At the same time, Berger $(1977,1978)$, using the much more accurate orbital calculations of Chapront et al. (1975), linked more reliably the insolation variations to the waxing and waning of the huge Northern Hemisphere ice sheets over North America, Greenland, Iceland and Europe, including the British Islands and Fennoscandia. The Quaternary period, however, also shows an intriguing transition between the $40 \mathrm{kyr}$ cycles that is dominant during the Early, or Lower, Pleistocene, i.e. from 2.6 Ma up to 1.25 Ma, and the dominant 100-kyr cycles of the

90 Mid- and Late, or Upper, Pleistocene, i.e. the last $800 \mathrm{kyr}$ that show longer glacials implying much larger continental ice sheets. The transition interval, between 1.25 Ma and 0.8 Ma, named the Mid-Pleistocene Transition (MPT: Pisias and Moore, 1981; Ruddiman et al., 1989), experienced variability that does not appear to be directly linked to insolation changes at high latitudes. In fact, the processes involved are not fully understood and still a matter of debate (Ghil \& Childress, 1987, Sec. 12.7; Ghil, 1994; Saltzman, 2002; Clark et 95 al., 2021).

Although the broad astronomic framework for past climate changes seems to be widely accepted, recent highresolution investigations in ice, marine and terrestrial records revealed much shorter periodicities than the orbital ones, as well as abrupt changes that do not match those attributed to variations in eccentricity, obliquity, or precession of the equinoxes. In this paper, we show that abrupt climate changes are still affected, albeit indirectly, by changes in insolation and hence in overall ice sheet volume. In this sense, the Milankovitch framework is shown herein to be still quite relevant to the study of abrupt and large climate changes.

The paper is organized as follows. In Sec. 2, proxy records for the last 3.2 Myr of Northern Hemisphere climate are described. In Sec. 3, we concentrate on the millennial-scale variability revealed by these records. In Sec. 4, we establish a connection between Dansgaard-Oeschger (DO) events and amended Bond cycles, and outline how global ice sheet volume affects the latter. Concluding remarks follow in Sec. 5.

\section{The Past 3.2 Myr History of the Northern Hemisphere Climate}

Over the past $66 \mathrm{Myr}$, corresponding to the Cenozoic Era, Earth's climate has experienced four main states, from "Warmhouse" and "Hothouse," between $66 \mathrm{Ma}$ and $34 \mathrm{Ma}$, to "Coolhouse" and "Icehouse," from $34 \mathrm{Ma}$

110 until the present time; see Fig. 1a. Although the first two states alternated in a warm-hot-warm sequence, the last two succeeded each other, thus generating the classical climate trend towards the recent ice age conditions (Zachos et al., 2001; Westerhold et al., 2020; Scotese et al., 2021).

The last 3.3 Myr have been defined as an Icehouse climate state, with the appearance of the Northern Hemisphere ice sheets and their variations through time (Westerhold et al., 2020). This Icehouse state is

115 characterized by a change of the interplay between benthic $\delta^{13} \mathrm{C}$ and $\delta^{18} \mathrm{O}$, which corresponds to a new relationship between the carbon cycle and climate (Turner, 2014). The past 3.2 Myr of Northern Hemisphere 
climate are particularly well described in North Atlantic core U1308 (Hodell and Channell, 2016). This core is located in the ice-rafted debris (IRD) belt (Ruddiman, 1977), and it yields a more complete record than U1313 (Naafs et al., 2013); see Fig. 1b. The variations of the benthic $\delta^{18} \mathrm{O}$ mostly indicate varying periodicities through time that correspond to periodicities in the orbital parameters of Earth's climate, as also pointed out by Lisiecki and Raymo (2005) from the stack oxygen isotope record they produced from 57 marine records covering the world's oceans.

However, several key features appear in the U1308 records during this time interval that are much more plausibly related to processes other than the orbital forcing. Hoddell and Channel (2016) identified four major steps in their climate record. These four steps are linked to thresholds in the benthic and bulk carbonate $\delta^{18} \mathrm{O}$ variations, and they occur at $2.75 \mathrm{Ma}, 1.5 \mathrm{Ma}, 0.9 \mathrm{Ma}$ and $0.65 \mathrm{Ma}$.

The first date is interpreted as corresponding to the earliest occurrence of IRD in the North Atlantic. This occurrence characterizes the presence of Northern Hemisphere coastal glaciers large enough to calve icebergs in the ocean, and the melting of these icebergs is likely to have impacted the oceanic circulation. Naafs et al.

130 (2013), however, reported the occurrence of weak IRD events in the late Pliocene that they attributed mainly to Greenland and Fennoscandian glaciers, and that point to larger ice sheets over these regions than during the later Quaternary, when North American ice sheets were considerably larger.

The second date corresponds to an increased amplitude in ice volume variations between glacial minima and interglacial optima. This second step shows the permanent occurrence of ice-rafted events during glacial intervals in the record, therefore an amplified relationship of climate variations with Northern Hemisphere ice sheets.

The third date, close to the MIS22-24 $\delta^{18} \mathrm{O}$ optima, shows increased continental ice volume in the Northern Hemisphere (Batchelor et al., 2019), but also more stability in the East Antractic ice sheet in Southern Hemisphere (Jakob et al., 2020). In parallel, evidence of a major glacial pulse recorded in Italy's Po Plain, as 140 well as in ${ }^{10} \mathrm{Be}$-dated boulders in Switzerland, is interpreted as marking the onset of the first major glaciation in the Alps (Knudsen et al., 2020; Muttoni et al., 2003). At about the same time, the synthetic Greenland $\delta^{18} \mathrm{O}$ reconstruction indicates the occurrence of millennial variability expressed by DO-like events (Barker et al., 2011).

The last date at $0.65 \mathrm{Ma}$ marks the end of the transition from the Lower and Mid-Pleistocene interval -

145 characterized by 41-kyr-dominated cycles and smaller 23-kyr ones - to the Upper Pleistocene, with its 100kyr-dominated cycles; see Fig. 1b. The sawtooth pattern of the interglacial-glacial cycles (Broecker and van Donk, 1970), which first becomes noticeable at $0.9 \mathrm{Ma}$, is well established during this final interval, in contradistinction with the previous, more smoothly shaped pattern that appears to follow the obliquity variations. The global ice volume is maximal, exceeding the values observed earlier in the record, especially due to the

150 larger contribution of the Northern American ice sheets. The latter now have a bigger impact on Northern Hemisphere climate than the Eurasian ice sheets (Batchelor et al., 2019). The IRD event intensity and frequency of occurrence increase (McManus et al., 1999) as well, leading to the major iceberg discharges into the North Atlantic named Heinrich events (HEs); see Heinrich (1988), Bond et al. (1992, 1993), and Obrochta et al. (2014). The interval of $1 \mathrm{Ma}-0.4 \mathrm{Ma}$ is also the interval during which Northern Hemisphere ice sheets reached their southernmost extent (Batchelor et al., 2019). 
The descriptions and classifications of climatic phenomena discussed so far were essentially subjective, being based on the mere visual inspection of the proxy records and on the previous experience of the investigators with the study of similar records. To gain further insight into the climate story the records tell us, we performed a quantitative, objective analysis of these time series of proxy variables, based on the recurrence plots (RPs) introduced by Eckmann et al. (1987) into the study of dynamical systems and popularized in the climate sciences by Marwan et al. $(2007,2013)$. The purpose of RPs is to identify recurring patterns in a time series in general and in a paleoclimate time series in particular.

The RP for a time series $\left\{x_{\mathrm{i}}: \mathrm{i}=1, \ldots, \mathrm{N}\right\}$ is constructed as a square matrix in a cartesian plane with the abscissa and ordinate both corresponding to a time-like axis, with one copy $\left\{x_{i}\right\}$ of the series on the abscissa

165 and another copy $\left\{x_{j}\right\}$ on the ordinate. A dot is entered into a position (i, j) of the matrix when $x_{j}$ is sufficiently close to $x_{i}$. For the details - such as how "sufficiently close" is determined - we refer to Eckmann et al. (1987) and to Marwan et al. (2013). Clearly, all the points on the diagonal $\mathrm{i}=\mathrm{j}$ have dots and, in general, the matrix is rather symmetric, although one does not always define closeness symmetrically; to wit, $x_{j}$ may be "closer to" $x_{i}$ than $x_{i}$ is to $x_{j}$ (Eckmann et al., 1987). An important advantage of the RP method is that it does

170 apply to dynamical systems that are not autonomous, i.e., that may be subject to time-dependent forcing. The latter is certainly the case for the climate system on time scales of 10-100 kyr and longer, which is affected strongly by orbital forcing.

Eckmann et al. (1987) distinguished between large-scale typology and small-scale texture in the interpretation of square matrix of dots that is the visual result of RP. Thus, if all the characteristic times of an autonomous

175 dynamical system are short compared to the length of the time series, the RP's typology will be homogeneous and, thus, not very interesting. In the presence of an imposed drift, a more interesting typology will appear. The most interesting typology in RP applications so far is associated with recurrent patterns that are not exactly periodic but only nearly so. Hence, such patterns are not that easily detectable by purely spectral approaches to time series analysis. Marwan et al. (2013) discuss how to render the purely visual RP typologies studied up

180 to that point more objectively quantifiable by recurrence quantification analysis and bootstrapping (Efron, 1981; Efron and Tibshirani, 1986).

The benthic $\delta^{18} \mathrm{O}$ record of the $\mathrm{U} 1308$ marine-sediment core is interpreted in terms of global ice volume and deep-ocean temperatures (Chappell and Shackleton, 1986; Shackleton, 2000; Elderfield et al., 2012). Its recurrence analysis shows a drift topology (Marwan et al., 2007) associated with nonstationary systems with

185 slowly varying parameters. The RP exhibits, moreover, a characteristic texture - given by the pattern of vertical and horizontal lines that mark recurrences. These lines sometimes form recurrence clusters that correspond to specific periodic patterns. We thus identify five steps in the $\delta^{18} \mathrm{O}$ variability (Fig. 2a, Tab. 1). Two are roughly similar to those determined by Hoddell and Channel (2016): at $1.5 \mathrm{Ma}$ and $0.65 \mathrm{Ma}$, and three differ: at $2.95 \mathrm{Ma}, 2.55 \mathrm{Ma}$, and 1.25 Ma. Interestingly, the interval 1.25 Ma to $0.65 \mathrm{Ma}$ corresponds roughly to

190 the previously mentioned MPT, during which a shift from climate cycles dominated by a 40-kyr periodicity to 100-kyr dominated ones occurred (Shackleton and Opdyke, 1977; Pisias and Moore, 1981; Ruddiman et al., 1989; Clark and Pollard, 1998; Clark et al., 2006).

The $\delta^{18} \mathrm{O}$ bulk carbonate record in the $\mathrm{U} 1308$ core, in turn, is interpreted as characterizing IRD released into the North Atlantic Ocean, with the most negative $\delta^{18} \mathrm{O}$ values representing the largest iceberg calvings (Hodell \& 
195 Channel, 2016). The recurrence analysis of this record also displays a drift topology, and it yields the two Hodell \& Channel (2016) steps at 1.5 Ma and 0.65 Ma (Fig. 3a, Tab. 1). Our analysis further identifies the steps at $0.9 \mathrm{Ma}$ and $2.75 \mathrm{Ma}$, however, it also detects other steps at $1.25 \mathrm{Ma}$ (also noticed for the $\delta^{18} \mathrm{O}$ ). Table 1, comparing Hodell \& Channel (2016) steps with the thresholds detected by the RP, shows that the former are mainly related to the IRD history of the past 3.3 Ma.

200 The $1.25 \mathrm{Ma}$ date is particularly significant, since it is followed by an increase in the amplitude of glacialinterglacial fluctuations. The interval 2.8 to $1.2 \mathrm{Ma}$ shows glacial-interglacial sea level variations of about 25-50 $\mathrm{m}$ below the present day. The $\mathrm{CO}_{2}$ concentrations varied between $270 \mathrm{ppmv}$ and $280 \mathrm{ppmv}$ during interglacials and between 210 ppmv and 240 ppmv during glacials, with a decreasing trend of about 23 ppmv over this 1.4Myr-long interval (van de Wal et al., 2011). After 1.25 Ma, the sea level changes decreased to about 70-120 m

205 below the present day, while the $\mathrm{CO}_{2}$ concentrations varied between 250 ppmv and 320 ppmv during interglacials and between 170 ppmv and 210 ppmv during glacials (Berends et al., 2021). Similar variations were determined by Seki et al. (2010), although $\mathrm{pCO}_{2}$ changes that occurred before the time reached by ice core records are associated with high uncertainties in both dating and values. The "Milanković glacials," which correspond to the odd marine isotope stages determined in the U1308 core and in many others, are

210 characterized by low eccentricity and obliquity, and a boreal summer that coincides with aphelion and leads, therefore, to minimum values of summer insolation. The increase in IRD variability and magnitude since $1.5 \mathrm{Ma}$, however, shows that distinct, faster processes have to be considered than those due to slow changes in Earth's orbital parameters; see again Figs. 2 and 3.

\section{Millennial-Scale Variability}

The behavior of the U1308 proxy records on the time scale of many tens and hundreds of thousands of years was described briefly in the previous section, and it allowed us to track the numerous glacial-interglacial cycles of the past 2.75 Myr with the help of variations in Earth's orbital parameters. Besides these relatively slow variations, evidence of millennial-scale variability can be observed since the appearance of IRD in the North

220 Atlantic at about $1.5 \mathrm{Ma}$; this much faster variability is superposed upon the classical orbital periodicities (Fig. 3).

Observations of such abrupt variations have been reported in some detail for the last glacial period, with the more or less regular recurrence of cold and warm events; see Fig. 1c. The former are represented by IRD events, some of which are significantly stronger, and represent the previously mentioned HEs that correspond to massive discharges of icebergs into the North Atlantic (Heinrich, 1988; Bond et al., 1992; McManus et al., 1994; Hemming, 2004).

Abrupt warmings happening over as little as a few decades each have been inferred from Greenland ice cores (Dansgaard et al., 1993; Clark et al., 1999), and labeled DOs or Greenland interstadials (Gls: Rasmussen et al., (2014) ; see Fig. 4a. These warm events are followed by a return to glacial conditions, called Greenland

230 stadials (GSs). This return generally happens in two steps, thus forming DO cycles of variable duration that does not exceed a millennial time scale (Broecker, 1994; Boers et al., 2018; Boers, 2018). As the periodicity of the events is at millennial and submillenial scale (Broecker, 1994; Clark et al., 1999; Ganopolski and Rahmstorf, 2001; Rahmstorf, 2002; Schulz, 2002; Menviel et al., 2014; Lohmann and Ditlevsen, 2018, 2019), it 
corresponds to processes that cannot be related to any orbital forcing (Lohmann et al., 2020), but rather to 235 factors that are intrinsic to the Earth System.

DO events were first observed in the various ice cores retrieved from the Greenland ice sheet (Dansgaard et al., 1969; Johnsen et al., 1972). Some of these DOs were correlated to European warm interstadials, which had been described from pollen records (Woillard, 1978, Behre, 1989; Zagwijn, 1989). The existence and dating of the DOs was initially questioned as they had not been observed in marine cores in the 1970s and 1980s

240 (Broecker et al., 1988; Broecker and Denton, 1989). Dansgaard et al (1993), though, clearly identified 23 rapid warming events during the last climate cycle from the Greenland GRIP ice core. These 23 DO events were later confirmed in other Greenland ice cores (Johnsen et al., 2001), and they are considered as the "canonical" DOs. They were assigned numbers increasing sequentially downcore, with \#1 allocated to the Bølling pollen oscillation (Dansgaard et al., 1993); see Fig. 4a.

245 The 23 canonical DOs were described later using various types of record, in marine sediments (Bond et al., 1992; Henry et al., 2016), as well as in terrestrial ones (Allen et al., 1999; Sanchez-Goni et al., 2000, 2002; Müller et al., 2003; Fletcher et al., 2010; Rousseau et al., 2017 a, b, 2021), including speleothems (Wang et al., 2001; Genty et al., 2003; Fleitmann et al., 2009; Boch et al., 2011). The increase in resolution of the Greenland ice core investigations (Fischer et al., 2015; Schupbach et al., 2018; Svensson et al., 2020) and of several

250 speleothems (Cheng et al., 2016) allowed one to conduct much more detailed analyses of the $\delta^{18} \mathrm{O}$ but also of other proxies, such as dust content, leading to the identification of sub-events, as compiled by Rasmussen et al. (2014). It is these high-resolution analyses that led to defining the Gls, followed by their associated GSs.

In addition to the unresolved dispute on defining this interstadial and stadial labeling (Rousseau et al., 2006), remains the status of and significance attributed to the smaller-scale events detected by Rasmussen et al.

255 (2014). Bagniewski_et_al. $(202020,2021)$ recently proposed a method based on an augmented nonparametric Kolmogorov-Smirnov (KS) test to detect abrupt transitions from paleo-records in a highly robust way. The classical KS test consists of quantifying and comparing the empirical distribution functions of two samples from a time series, before and after a potential jump. In the present case, the test is augmented by varying window sizes, and evaluating the rate of change and the trend in maxima and minima of the time series, thus

260 establishing the main transitions in a record, such as the GS-GI boundaries in the North Greenland Ice Core Project (NGRIP) $\delta^{18} \mathrm{O}$. The transitions identified by this methodology include all the canonical events described by Rasmussen et al. (2014), although a few other DOs or subevents are not detected by it, even after changing the test window size.

Using a global climate indicator like methane $\left(\mathrm{CH}_{4}\right.$ : Blunier and Brook, 2001), EPICA Community Members

265 (2006) and the WAIS Consortium (2015) demonstrated that the millennial-scale variations observed during the last $130 \mathrm{kyr}$ in Greenland are observed in Antarctica as well, and that they are, therefore, a global phenomenon. The $\delta^{18} \mathrm{O}$ variations in two hemispheres, though, are in opposite phases, with Southern Hemisphere warmings occurring prior the Northern Hemisphere ones.

Several hypotheses have been proposed to determine whether the climatic signal propagated between the two

270 hemispheres is in a southward or northward direction. Variations in the Atlantic Meridional Overturning Circulation (AMOC) play a key role in this teleconnection as AMOC slowdown during GSs corresponds to reduced northward heat transport (Sarnthein et al., 2001; Ganopolski and Rahmstorf, 2001; McManus et al., 2004). Detailed high-resolution marine-sediment and ice core studies (Buizert et al., 2015a; Henry et al., 
2016), on the other hand, indicate a southward propagation of the anomalies, with Greenland climate leading Antarctica by approximately 200 years. At this point, one can only state that the latter, observational studies do not contradict the earlier, modeling studies, but do not directly confirm them either.

To address this issue, Boers et al. (2018) recently developed a simple model to reconstruct the millennial variability in $\delta^{18} \mathrm{O}$ of the past $60 \mathrm{kyr}$ b2K, as observed in the high-resolution ice cores from NGRIP in Greenland and West Antarctic Ice Sheet (WAIS) in Antarctica. This simple model, based on the bipolar seesaw mechanism of Stocker and Johnsen (2003), combines the interactions between ice shelves and sea ice extents, subsurface water temperatures in the North Atlantic Ocean, atmospheric temperature in Greenland, the AMOC strength, and $\delta^{18} \mathrm{O}$ in both Greenland and Antarctica. The interplay of the feedbacks involved allowed the authors to reproduce the millennial-scale variability observed in both hemispheres, despite the lack of any time-dependent forcing that would involve orbital parameters, whether subsumed by the $65^{\circ} \mathrm{N}$ summer insolation curve or not.

\section{DO events and Bond cycles}

The results outlined in the previous section have led us to concentrate on the canonical DOs for which the

290 temperature reconstruction has been proposed based on ${ }^{15} \mathrm{~N}$ measurements from the Greenland ice (Guillevic et al., 2014). These estimates indicate that the 21 warming events during the last climate cycle, between $12 \mathrm{ka}$ and $87 \mathrm{ka} \mathrm{b2k}$, had on average a range of $10^{\circ} \mathrm{C}-12^{\circ} \mathrm{C}$ (Kindler et al., 2014), with each transition lasting on average between $50 \mathrm{yr}$ and $100 \mathrm{yr}$ (Wolff et al., 2010; Rousseau et al., 2017a, b, 2021), as found at least near the top of the Greenland ice sheet at the coring site. Not only does the change in temperature over such a short

295 time imply a drastic reorganization of the atmospheric, and associated marine, circulations (Boers et al., 2018), but the timing does not correspond to any periodicity of the orbital parameters, neither in the average duration of the events, nor in the average interval between two such events.

The recurrence analysis performed on the high-resolution NGRIP $\delta^{18} \mathrm{O}$ record and illustrated in Fig. 4b suggests looking for other mechanisms that might cause the abrupt changes mentioned previously. As for the

$300 \quad \delta^{18} \mathrm{O}$ record analysis in core U1308 displayed in Fig. 3, the NGRIP study shows a drift topology but with a nonuniform pattern. Several thresholds are identified which correspond to key dates of the last climate cycle stratigraphy (Bassinot et al., 1994; McManus et al., 1994; Kukla et al., 1997; Lisiecki and Raymo, 2005; Clark et al., 2009); see Tab. 2.

When plotted in Fig. 4c against the variations in global sea level deduced from North Atlantic and Equatorial

305 Pacific $\delta^{18} \mathrm{O}$ benthic records by Waelbroeck et al. (2002), the length of the Gls appears to be related to the mean sea level. The long Gls occurred between 120 and 80 ka b2k, and between 59 and 40 ka b2k. During these two intervals, the global sea level exhibited relatively slight variations between about $-15 \mathrm{~m}$ and $-45 \mathrm{~m}$ and about $-50 \mathrm{~m}$ and $-75 \mathrm{~m}$, respectively. Conversely, after $80 \mathrm{ka}$ b2K and after $32 \mathrm{ka}$ b2k, Gls were shorter and occurred during the most abrupt drops in sea level of the last climate cycle, from $-15 \mathrm{~m}$ to $-85 \mathrm{~m}$, and from

$310-50 \mathrm{~m}$ down to a minimum of about $-120 \mathrm{~m}$ during the Last Glacial Maximum. The agreement between the results of the recurrence analysis and the NGRIP $\delta^{18} \mathrm{O}$ transitions, as well as the link between the length of Gls and the global sea level variations, seems to establish a relation between the variation in GI length and the 
spatial extent and elevation of the largest continental ice sheets, especially in the Northern Hemisphere, with the latter expanding further inland and out onto the continental shelf during the last climate cycle.

315 The DO cycles have been grouped together following an increasing cooling trend of the GSs and subsequent to a strong DO event (Bond et al., 1992; Alley, 1998; Alley et al., 1999; Clark et al., 2007). This cooling trend ends with a final and coldest GS that coincides with an HE. These groupings have been named Bond cycles (Broecker, 1994; Alley, 1998), and they have been observed mainly in North Atlantic marine records of the last climate cycle with a rough periodicity of $7 \mathrm{kyr}$ (Clark et al., 2007); see Fig. 5. These Bond cycles, like the DO cycles, have no relationship with the periodicity of the orbital parameters, but they are in excellent agreement with the robust 6-7 kyr periodicity of a natural, intrinsic paleoclimate oscillator (Källén et al., 1979; Ghil and Le Treut, 1981).

This oscillator is based on the countervailing effects of the positive ice-albedo feedback on Earth's radiation balance - with temperatures drops that are enhanced by the increasing extent of sea ice (Budyko, 1969;

325 Sellers, 1969) - and of the negative precipitation-temperature feedback on the mass balance of ice sheets, with temperature increases that contribute to increased accumulation of the ice (Källén et al., 1979; Miller and de Vernal, 1992; Ghil, 1994; Tziperman and Gildor, 2003). Ghil and Tavantzis (1983) showed that the oscillator's 6-7 kyr periodicity is quite stable over a substantial range of parameter values, and Ghil (1994) noted that this periodicity was predicted by Källén et al. (1979), well before the HEs were discovered by

330 Heinrich (1988). More recently, the HEs' approximate recurrence time was found to be equal roughly to this periodicity by Clark et al. (2007, and references therein), in spite of the fact that these authors were not aware of its theoretical prediction of M. Ghil and coauthors (Källén et al., 1979; Ghil and Le Treut, 1981; Ghil, 1994).

The HEs events are believed to first occur at about $0.65 \mathrm{Ma}$, as can be deduced from the U1308 benthic and bulk carbonate $\delta^{18} \mathrm{O}$ records. The GSs' duration has sometimes been incorrectly linked with the occurrence of an $\mathrm{HE}$, leading to the misinterpretation of HEs as being equivalent to GSs. A detailed study of a subset of GSs has demonstrated that HEs did not last the entire duration of a GS (Guillevic et al., 2014), indicating a much more complex dynamics of the cold stadials themselves than had initially been considered. Such complex climate behavior, by extension, may have prevailed since the first occurrence of HEs in the North Atlantic at about 0.65 Ma. Moreover, Bond and Lotti (1995) demonstrated that although an HE was embedded into the

340 final GS of the Bond cycles, additional IRD events, of lower magnitude than an HE, were also embedded in the previous and intermediary GSs.

Therefore, the previous definition of the Bond cycles given by Broecker (1994) and Alley (1998), could be amended by including the IRD events embedded in every stadial. Thus Bond cycles should be interpreted as a sequence of DO cycles, which start with a distinctly warm Gl, followed by a cooling trend with increasingly

345 colder GSs that include as many IRD events as identified stadials, the latest of which is an HE; see Fig. 6a. The synthetic Greenland $\delta^{18} \mathrm{O}$ record reconstructed from the EPICA data over the last 800 ka by applying the bipolar seesaw model (Barker et al., 2011) indicates that DO cycles have occurred at least during this time interval. This synthetic record is, furthermore, well correlated with $\delta^{18} \mathrm{O}$ variations observed from Chinese speleothems (Cheng et al., 2016). Hence, the millennial variability associated with the DO cycles is likely to

350 have prevailed since $0.8 \mathrm{Ma}$, or even since $0.9 \mathrm{Ma}$, when the global ice volume strongly increased, as indicated by MIS $22 \delta^{18} \mathrm{O}$ and sea level values. However, since IRD delivery to the North Atlantic requires ice sheets to reach the ocean, and since the first IRD are recorded in the North Atlantic at about 1.5 Ma (Hodell and 
Channell, 2016), one could assume that the start of this type of millennial variability occurred as early as this older threshold. Whether a younger start date of $0.9 \mathrm{Ma}$, or an older one of $1.5 \mathrm{Ma}$, is posited, these results show that the Northern Hemisphere ice sheets played a significant role in the onset of millennial and submillennial climate variability that prevailed during the Mid and Late Pleistocene.

Ziemen et al. (2019) simulated HEs following the Binge-Purge model of MacAyeal (1993) and reported a twostep mechanism. The first step is a surge phase with enhanced fresh water discharge weakening the deep water formation due to the stratification of the surface water, increased sea ice cover, and leading to reduced

360 North Atlantic sea surface temperature due to a weakened AMOC, reduced evaporation and precipitation. The second step corresponds to a post-surge phase with a much lowered elevation of the Laurentide ice sheet that may have lost several hundreds of meters or more during the massive iceberg discharges. During the postsurge phase described by Ziemen et al. (2019), a higher sea level associated with the lower elevation of the ice sheet favors the northern polar jet to move northwards, which leads to more precipitation over Hudson Bay,

365 speeds up the regrowth of the Laurentide ice sheet, and results in the start of a new Bond cycle. A similar mechanism, albeit of lower magnitude, could be considered for the other iceberg discharges occurring during GS, which did not yield HEs. Such a mechanism may apply, with a reduced amplitude, to the smaller Eurasian ice sheets that were also involved in the release of icebergs during HEs. The Ziemen et al. (2019) mechanism appears, moreover, to be in agreement with the $\mathrm{Mg} / \mathrm{Ca}$ data on benthic foraminifera studied by Marcott et al.

370 (2011). These authors found that warming of the subsurface temperature of the high-latitude North Atlantic lead to increased basal melting under ice shelves, accelerated their collapse as suggested by Boers et al. (2018), and thus drove the Hudson Strait Ice Stream of the Laurentide ice sheet to release IRD deposited as HEs (Alvarez-Solas and Ramstein, 2011); see Fig. 6b.

Guillevic et al. (2014) studied ${ }^{17} \mathrm{O}$ excess variations in Greenland ice cores, which characterize changes in the

375 lower-latitude hydrological cycle, and reported that, at least for HE4 and HE5, iceberg delivery to the North Atlantic did not last the whole GS duration. Instead, this delivery occurred about a hundred years after the start of the GS. This short interval seems to correspond to the time during which the subsurface warming of the ocean was linked to an expansion of the sea ice and the ice shelves, as mentioned by Marcott et al. (2011) and Boers et al. (2018), and it also corresponds to "pre-surge" conditions, according to the Ziemen et al. (2019)

380 model, increasing the flow of ice beyond a certain threshold leads to the massive calving of icebergs (surge phase). Furthermore, Guillevic et al. (2014) indicate that the HE4 post-surge started during GS9, hundreds of years prior to the start of the warming corresponding to Gl8.

These sequences - starting with a strong GI, followed by intermediary GSs that include IRD events, and ending with a colder GS that includes an HE, see Fig. $6 \mathrm{a}$ - must have repeated throughout the last climate

385 cycle, most likely so during the glacial interval from $116 \mathrm{ka}$ b2k on (Bond and Lotti, 1995). In fact, HEs are believed to first occur at about $0.65 \mathrm{Ma}$, although $\mathrm{DO}$ events may have occurred independently since about 0.8 Ma or even $0.9 \mathrm{Ma}$. It thus appears that the millennial and sub-millennial variability corresponding to the Bond cycles involves variations in size and elevation of the Northern Hemisphere ice sheets that give rise to the iceberg release events into the North Atlantic; see Fig. 6b. This mechanism may have played a key role during

390 the past 0.8 Myr-0.9 Myr, when the Northern Hemisphere ice sheets were at their maximum size and extended out over the continental shelf. This combination of size and contact with the much warmer ocean is likely to have destabilized the ice sheets around the North Atlantic and led to massive IRD events. The appearance of 
IRD in the North Atlantic Ocean, though, might have occurred as early as $1.5 \mathrm{Ma}$ (Hodell \& Channel, 2016), a fact that could indicate the type of relatively short-periodic variability discussed herein prevailing over the last 1.5 Myr.

In any case, a time interval of the most recent $0.8 \mathrm{Myr}-1.5 \mathrm{Myr}$ seems to have witnessed millennial-scale climate variability whose amplitude exceeded the one that was directly forced by the orbital periodicities (Ghil and Childress, 1987; Ghil, 1994; Ghil, 2021). This fairly well-agreed-upon fact leads support to the interpretation of the enhanced millennial variability during glacial times as arising from an internal oscillation of the climate system - as proposed by several authors, such as Källèn et al. (1979), Le Treut et al. (1988), Saltzman (2002) and Crucifix (2012), among others - while Hodell and Channell (2016) only considered it as noise superimposed on the orbital variability deduced from their wavelet analysis of the benthic $\delta^{18} \mathrm{O}$ record of U1308. Substantial, nonlinear interactions between internal, oscillatory variability and orbital forcing are actively being explored by Riechers et al. (2021) this special issue.

405

\section{Concluding remarks}

Our quick overview of millennial-scale climate variability over the last 3.2 Myr suggests the following conclusions:

- The key phenomena that characterize this millennial-scale variability are Heinrich events (HEs), Dansgaard-Oeschger (DO) events, and Bond cycles. Abrupt changes are intimately interwoven with these phenomena.

- Present investigations point to internal mechanisms being responsible for these millennial-scale events and for the associated abrupt changes. These mechanisms include internal oscillations of the ice sheet-ocean-atmosphere system and episodic calving of ice sheets.

415 - The Bond cycles are linked to the dynamics of the Northern Hemisphere ice sheets, specifically to variations in their spatial extent and their elevation. These Bond cycles illustrate a much more complex millennial variability than initially contemplated, by considering the DO and HE not individually, but linking them into a unified story.

- Millennial-scale variability is observed in proxy records from the very beginning of the last glacial period, and during previous glacial periods, at least since 0.8-0.9 Ma, when HEs first appear in the records. This timing seems to coincide roughly with the MPT that has been associated with a global increase in ice volume on Earth. This coincidence does not exclude the possibility of an even earlier appearance of millennial variability, given the first appearance of IRD events as early as $1.5 \mathrm{Ma}$.

- Dynamical interactions between the ocean, the cryosphere with its continental ice sheets and sea ice cover, and the atmosphere are at play in generating the millennial-scale variability that leads to abrupt climate changes. The specific mechanisms of these interactions, though, are still being elucidated.

- Even so, we have seen that orbital forcing, as postulated by Milankovitch, sets the stage for these internal processes and modulates their period and amplitude.

Orbital-scale and millennial variability appear to interact during the Quaternary, with millennial variability

430 increasing in intensity as ice sheets grew larger in both area and volume. Thus, abrupt climate changes are undoubtedly related, albeit indirectly, to the astronomical theory of climate. 
Author contributions

DDR designed the project and drafted the paper. WB performed the recurrence analyses. All the authors contributed to the writing of the paper. DDR and MG finalized the paper.

\section{Competing interest}

The authors declare that they have no conflict of interest. The lead author, as a co-chief editor of Climate of the Past, did not have access to the whole review process.

\section{Acknowledgements}

The authors thank the editor and the reviewers for their handling of the paper. It is a pleasure to acknowledge Laurie Menviel for providing the sea surface maps used in figure 6 and Peter Clark for his comments on the draft of this manuscript. This paper has been presented at the Milankovich symposium held in 2020 to celebrate the centennial of the Milankovitch (1920) book. The authors sincerely thank the meeting organizers for inviting the lead author. DDR, WB and MG are funded by the European Union's Horizon 2020 research and innovation programme through the TiPES grant no. 820970. This is LDEO contribution (no. ZZZ), and TiPES contribution (no. x).

Financial support

This research has been supported by the European Union's Horizon 2020 research and innovation programme (TiPES grant no. 820970).

Datasets used

The datasets used include the following:

455 - Waelbroeck, C.; Labeyrie, L.D.; Michel, E.; Duplessy, J.-C.; McManus, J.F.; Lambeck, K.; Balbon, E.; Labracherie, M. (2010-11-16): NOAA/WDS Paleoclimatology - Sea-level and Deep Water Temperature $430 \mathrm{kyr}$ Reconstructions. NOAA National Centers for Environmental Information. https://www.ncdc.noaa.gov/paleo/study/10496.

460 - Hodell, D. A.; Channell, J. E. T. (2016): Foraminiferal stable isotopes and physical properties from North Atlantic sediment cores for the past 3.2 million years. PANGAEA, https://doi.org/10.1594/PANGAEA.871937, Supplement to: Hodell, DA; Channell, JET (2016): Mode transitions in Northern Hemisphere glaciation: co-evolution of millennial and orbital variability in Quaternary climate. Climate of the Past, 12(9), 1805-1828, https://doi.org/10.5194/cp-12-1805-2016

- Westerhold, Th. (2020): Cenozoic global reference benthic carbon and oxygen isotope dataset (CENOGRID). PANGAEA, https://doi.org/10.1594/PANGAEA.917503

- Rasmussen, S. O., Bigler, M., Blockley, S. P., Blunier, T., Buchardt, S. L., Clausen, H. B., Cvijanovic, I., Dahl-Jensen, D., Johnsen, S. J., Fischer, H., Gkinis, V., Guillevic, M., Hoek, W. Z., Lowe, J. J., Pedro, J. B., Popp, T., Seierstad, I. K., Steffensen, J. P., Svensson, A. M., Vallelonga, P., Vinther, B. M., Walker, M. J. C., Wheatley, J. J., and Winstrup, M.: A stratigraphic framework for abrupt climatic changes during the Last Glacial period based on three synchronized Greenland ice-core records: refining and extending the INTIMATE event stratigraphy, Quat. Sci. Rev., 106, 14-28, 
https://doi.org/10.5194/cp-2021-103

Preprint. Discussion started: 11 August 2021

(c) Author(s) 2021. CC BY 4.0 License.

(c) (i)

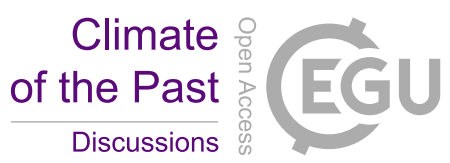

475 https://www.iceandclimate.nbi.ku.dk/data/GICC05modelext_GRIP_and_GISP2_and_resampled_data_s eries_Seierstad_et_al._2014_version_10Dec2014-2.xlsx

- Bond, Gerard C; Heinrich, Hartmut; Broecker, Wallace S; Labeyrie, Laurent D; McManus, Jerry F; Andrews, John T; Huon, Sylvain; Jantschik, Ruediger; Clasen, Silke; Simet, Christine; Tedesco, Kathy; Klas, Mieczyslawa; Bonani, Georges; Ivy, Susan; Obrochta, Stephen P (2012): (Table S3) Abundance of Neogloboquadrina pachyderma (s) in MIS4-2 of DSDP Site 94-609. PANGAEA, https://doi.org/10.1594/PANGAEA.834692, In supplement to: Obrochta, Stephen P; Miyahara, Hiroko; Yokoyama, Yusuke; Crowley, Thomas J (2012): A re-examination of evidence for the North Atlantic "1500-year cycle" at Site 609. Quat. Sci. Rev., 55, 23-33, https://doi.org/10.1016/j.quascirev.2012.08.008 


\section{References}

Adhémar, J.: "Révolutions de la mer, déluges périodiques", Carilian-Goeury et V. Dalmont, Paris, 1842.

Agassiz, L.: Glaciers, Moraines, and Erratic Blocks, The Edinburgh New Philosophical Journal, 24, 364-383, 1838.

Agassiz, L.: Glaciers and the evidence of their having once existed in Scotland, Ireland and England, Proc. Geol. Soc. London, III, Part II, 327-332, 1842.

Allen, J. R. M., Brandt, U., Brauer, A., Hubberten, H. W., Huntley, B., Keller, J., Kraml, M., Mackensen, A., Mingram, J., Negendank, J. F. W., Nowaczyk, N. R., Oberhansli, H., Watts, W. A., Wulf, S., and Zolitschka, B.: Rapid environmental changes in southern Europe during the last glacial period, Nature, 400, 740-743, 1999.

Alley, R. B.: Palaeoclimatology - Icing the north Atlantic, Nature, 392, 336-337, https://doi.org/10.1038/32781, 1998.

500 Alley, R. B., Clark, P. U., Keigwin, L. D., and Webb, R. S.: Making sense of millenial-scale climate change, In: Mechanisms of global climate change at millenial time scales, edited by: Clark, P. U., Webb, R., and Keigwin, L. D., Geophysical Monograph. AGU, 385-394, https://doi.org/10.1029/GM112p0385, 1999.

Alvarez-Solas, J. and Ramstein, G.: On the triggering mechanism of Heinrich events, Proc. Natl. Acad. Sci. U. S. A. 108, E1359-E1360, https://doi.org/10.1073/pnas.1116575108, 2011.

Bagniewski, W., Ghil, M., and Rousseau, D.-D.: Tipping points in the climate system: Automatic detection of abrupt transitions in paleoclimate records, [preprint] American Geophysical Union Fall Meeting 2020, https://doi.org/10.1002/essoar.10506097.1.

Bagniewski, W., Ghil, M., and Rousseau, D. D.: Automatic detection of abrupt transitions in paleoclimate records, Chaos, in review, 2021.

510 Barbante, C., Barnola, J. M., Becagli, S., Beer, J., Bigler, M., Boutron, C., Blunier, T., Castellano, E., Cattani, O., Chappellaz, J., Dahl-Jensen, D., Debret, M., Delmonte, B., Dick, D., Falourd, S., Faria, S., Federer, U., Fischer, H., Freitag, J., Frenzel, A., Fritzsche, D., Fundel, F., Gabrielli, P., Gaspari, V., Gersonde, R., Graf, W., Grigoriev, D., Hamann, I., Hansson, M., Hoffmann, G., Hutterli, M. A., Huybrechts, P., Isaksson, E., Johnsen, S., Jouzel, J., Kaczmarska, M., Karlin, T., Kaufmann, P., Kipfstuhl, S., Kohno, M., Lambert, F., Lambrecht, A., Lambrecht, A., Landais, A., Lawer, G., Leuenberger, M., Littot, G., Loulergue, L., Luthi, D., Maggi, V., Marino, F., Masson-Delmotte, V., Meyer, H., Miller, H., Mulvaney, R., Narcisi, B., Oerlemans, J., Oerter, H., Parrenin, F., Petit, J. R., Raisbeck, G., Raynaud, D., Rothlisberger, R., Ruth, U., Rybak, O., Severi, M., Schmitt, J., Schwander, J., Siegenthaler, U., Siggaard-Andersen, M. L., Spahni, R., Steffensen, J. P., Stenni, B., Stocker, T. F., Tison, J. L., Traversi, R., Udisti, R., Valero-Delgado, F., van den Broeke, M. R., van de Wal, R. S. W., Wagenbach, D., Wegner, A., Weiler, K., Wilhelms, F., Winther, J. G., Wolff, E., and Epica Community Members: One-to-one coupling of glacial climate variability in Greenland and Antarctica, Nature, 444, 195-198, https://doi.org/10.1038/nature05301, 2006.

Barker, S., Knorr, G., Edwards, R. L., Parrenin, F., Putnam, A. E., Skinner, L. C., Wolff, E., and Ziegler, M.: 800,000 Years of Abrupt Climate Variability, Science, 334, 347-351, 
Bassinot, F. C., Labeyrie, L. D., Vincent, E., Quidelleur, X., Shackleton, N. J., and Lancelot, Y.: The astronomical theory of climate and the age of the Brunhes-Matuyama magnetic reversal, Earth Planet. Sci. Lett.,126, 91-108, 1994.

Batchelor, C. L., Margold, M., Krapp, M., Murton, D., Dalton, A. S., Gibbard, P. L., Stokes, C. R., Murton, J. B., and Manica, A.: The configuration of Northern Hemisphere ice sheets through the Quaternary, Nature Commu.,10, https://doi.org/10.1038/s41467-019-11601-2, 2019.

Behre, K. E.: Biostratigraphy of the last glacial period in Europe, Quat. Sci. Rev. 8, 25-44, 1989.

Benn, D. I., Le Hir, G., Bao, H. M., Donnadieu, Y., Dumas, C., Fleming, E. J., Hambrey, M. J., McMillan, E. A., Petronis, M. S., Ramstein, G., Stevenson, C. T. E., Wynn, P. M., and Fairchild, I. J.: Orbitally forced ice sheet fluctuations during the Marinoan Snowball Earth glaciation, Nat. Geosci., 8, 704-707, https://doi.org/10.1038/ngeo2502, 2015.

Berends, C. J., de Boer, B., and van de Wal, R. S. W.: Reconstructing the evolution of ice sheets, sea level, and atmospheric CO2 during the past 3.6 million years, Clim. Past, 17, 361-377, https://doi.org/10.5194/cp17-361-2021, 2021.

540 Berger, A. L.: Support for the astronomical theory of climatic changes, Nature., 269, 44-45, https://doi.org/10.1038/269044a0, 1977.

Berger, A. L.: Long-term variations of caloric insolation resulting from the Earth's orbital elements. Nature, 9, 139-167, 1978.

Blunier, T. and Brook, E. J.: Timing of millennial-scale climate change in Antarctica and Greenland during the last glacial period, Science, 291, 109-112, https://doi.org/10.1126/science.291.5501.109, 2001.

Boch, R., Cheng, H., Spotl, C., Edwards, R. L., Wang, X., and Hauselmann, P.: NALPS: a precisely dated European climate record 120-60 ka, Clim. Past, 7, 1247-1259, https://doi.org/10.5194/cp-7-1247-2011, 2011.

Boers, N.: Early-warning signals for Dansgaard-Oeschger events in a high-resolution ice core record, Nature Commu., 9, https://doi.org/10.1038/s41467-018-04881-7, 2018.

Boers, N., Ghil, M., and Rousseau, D.-D.: Ocean circulation, ice shelf, and sea ice interactions explain Dansgaard-Oeschger cycles, Proc. Natl. Acad. Sci. U. S. A., 115, E11005-E11014, https://doi.org/10.1073/pnas.1802573115, 2018.

Bond, G., Heinrich, H., Broecker, W., Labeyrie, L., McManus, J., Andrews, J., Huon, S., Jantschik, R., Clasen, S., Simet, C., Tedesco, K., Klas, M., Bonani, G., and Ivy, S.: Evidence for massive discharges of icebergs into the North Atlantic Ocean during the last glacial period, Nature, 360, 245-249, 1992.

Bond, G., Broecker, W., Johnsen, S., McManus, J., Labeyrie, L., Jouzel, J., and Bonani, G.: Correlations between climate records from North Atlantic sediments and Greenland ice, Nature, 365, 143-147, 1993.

Bond, G. C. and Lotti, R.: Iceberg discharges into the North Atlantic on millennial time scales during the last glaciation, Science, 267, 1005-1010, 1995.

Broecker, W. S.: Massive iceberg discharges as triggers for global climate change, Nature, 372, 421-424, 1994.

Broecker, W. S., and J. van Donk: Insolation changes, ice volumes, and $0^{18}$ record in deep-sea cores, Rev. Geophys. Space Phys., 8, 1,169-198, https://doi.org/10.1029/RG008i001p00169, 1970 
Broecker, W. S. and Denton, G.: The role of ocean-atmosphere reorganizations in glacial cycles, Geochim. Cosmochim. Acta, 53, 2465-2501, 1989.

Broecker, W. S., Andree, M., Bonani, G., Wolfi, W., Oeschger, H., and Klas, M.: Can the Greenland climatic jumps be identified in records from ocean and land? Quat. Res., 30, 1-6, 1988.

Budyko, M. I.: The effect of solar radiation variations on the climate of the Earth. Tellus, 21, 611-619, 1969.

Buizert, C., Adrian, B., Ahn, J., Albert, M., Alley, R. B., Baggenstos, D., Bauska, T. K., Bay, R. C., Bencivengo, B. B., Bentley, C. R., Brook, E. J., Chellman, N. J., Clow, G. D., Cole-Dai, J., Conway, H., Cravens, E., Cuffey, K. M., Dunbar, N. W., Edwards, J. S., Fegyveresi, J. M., Ferris, D. G., Fitzpatrick, J. J., Fudge, T. J., Gibson, C. J., Gkinis, V., Goetz, J. J., Gregory, S., Hargreaves, G. M., Iverson, N., Johnson, J. A., Jones, T. R., Kalk, M. L., Kippenhan, M. J., Koffman, B. G., Kreutz, K., Kuhl, T. W., Lebar, D. A., Lee, J. E., Marcott, S. A., Markle, B. R., Maselli, O. J., McConnell, J. R., McGwire, K. C., Mitchell, L. E., Mortensen, N. B., Neff, P. D., Nishiizumi, K., Nunn, R. M., Orsi, A. J., Pasteris, D. R., Pedro, J. B., Pettit, E. C., Price, P. B., Priscu, J. C., Rhodes, R. H., Rosen, J. L., Schauer, A. J., Schoenemann, S. W., Sendelbach, P. J., Severinghaus, J. P., Shturmakov, A. J., Sigl, M., Slawny, K. R., Souney, J. M., Sowers, T. A., Spencer, M. K., Steig, E. J., Taylor, K. C., Twickler, M. S., Vaughn, B. H., Voigt, D. E., Waddington, E. D., Welten, K. C., Wendricks, A. W., White, J. W. C., Winstrup, M., Wong, G. J., Woodruff, T. E., and WAIS Divide Project Members: Precise interpolar phasing of abrupt climate change during the last ice age, Nature, 520, 661-U169, https://doi.org/10.1038/nature14401, 2015a.

Buizert, C., Cuffey, K. M., Severinghaus, J. P., Baggenstos, D., Fudge, T. J., Steig, E. J., Markle, B. R., Winstrup, M., Rhodes, R. H., Brook, E. J., Sowers, T. A., Clow, G. D., Cheng, H., Edwards, R. L., Sigl, M., McConnell, J. R., and Taylor, K. C.: The WAIS Divide deep ice core WD2014 chronology - Part 1: Methane synchronization (68-31 ka BP) and the gas age-ice age difference, Clim. Past, 11, 153-173, https://doi.org/10.5194/cp-11-153-2015, 2015b.

Chappell, J., and Shackleton, N. J.: Oxygen isotopes and sea level, Nature 324, 137-140, 1986.

Chapront, J., Bretagnon, P., and Mehl, M.: Un formulaire pour le calcul des perturbations d'ordres élevés dans 590 les problèmes planétaires. Celest. Mech., 11(3), 379-399, 1975.

Cheng, H., Edwards, R. L., Sinha, A., Spotl, C., Yi, L., Chen, S. T., Kelly, M., Kathayat, G., Wang, X. F., Li, X. L., Kong, X. G., Wang, Y. J., Ning, Y. F., and Zhang, H. W.: The Asian monsoon over the past 640,000 years and ice age terminations, Nature, 534, 640-646, https://doi.org/10.1038/nature18591, 2016.

Clark, P. U. and Pollard, D.: Origin of the middle Pleistocene transition by ice sheet erosion of regolith, Paleoceanography, 13, 1-9, 1998.

Clark, P. U., Alley, R. B., and Pollard, D.: Climatology - Northern Hemisphere ice-sheet influences on global climate change, Science, 286, 1104-1111, https://doi.org/10.1126/science.286.5442.1104, 1999.

Clark, P. U., Archer, D., Pollard, D., Blum, J. D., Rial, J. A., Brovkin, V., Mix, A. C., Pisias, N. G., and Roy, M.: The middle Pleistocene transition: characteristics, mechanisms, and implications for long-term changes in atmospheric $\mathrm{pCO}_{2}$, Quat. Sci. Rev., 25, 3150-3184, https://doi.org/10.1016/j.quascirev.2006.07.008, 2006.

Clark, P. U., Hostetler, S. W., Pisias, N. G., Schmittner, A., and Meissner, K. J.: Mechanisms for an 7-kyr climate and sea-level oscillation during marine isotope stage 3 , in: Ocean circulation: Mechanism and Impacts: Past and Future changes of Meridional Overturning, edited by: Schmittner, A., Chiang, J. C. H., and Hemming, S. R., AGU Monograph 173, 209-246, 2007. 
Clark, P. U., Dyke, A. S., Shakun, J. D., Carlson, A. E., Clark, J., Wohlfarth, B., Mitrovica, J. X., Hostetler, S. W., and McCabe, A. M.: The Last Glacial Maximum, Science, 325, 710-714, https://doi.org/10.1126/science.1172873, 2009.

Clark, P. U., Shakun, J., Rosenthal, Y., Köhler, P., Schrag, D., Pollard, D., Liu, Z., Bartlein, P., and EGU: Requiem for the Regolith Hypothesis: Sea-Level and Temperature Reconstructions Provide a New Template

610 for the Middle Pleistocene Transition, EGUsphere [preprint], https://doi.org/10.5194/egusphere-egu2113981, May 2021.

Croll, J.: "Climate and Time, in Their Geological Relations", D. Appletown and Co., New York, 1890.

Crucifix, M.: Oscillators and relaxation phenomena in Pleistocene climate theory, Philosophical Transactions of the Royal Society A, 370, 1140-1165, 2012.

615 Dansgaard, W., Johnsen, S. J., Moller, J., and Langway, C. C.: One thousand centuries of climatic record from Camp Century on the Greenland ice sheet. Science, 166, 377-381, 1969.

Dansgaard, W., Johnsen, S. J., Clausen, H. B., Dahi-Jensen, D., Gundestrup, N. S., Hammer, C. U., Hvidberg, C. S., Steffensen, J. P., Sveinbjöprnsdottir, A. E., Jouzel, J., and Bond, G.: Evidence for general instability of past climate from a 250-kyr ice-core record. Nature, 364, 218-220., 1993.

Drury, A. J., Liebrand, D., Westerhold, T., Beddow, H. M., Hodell, D. A., Rohlfs, N., Wikens, R. H., Lyle, M., Bell, D. B., Kroon, D., Pälike, H., and Lourens, L. J.: Climate, cryosphere and carbon cycle controls on Southern Atlantic orbital-scale carbonate deposition since the Oligocene (30-0 Ma), Clim. Past [preprint], https://doi.org/10.5194/cp-2020-108, 2020.

Eckmann, J. P., Kamphorst, S. O., and Ruelle, D.: Recurrence plots of dynamical systems. Europhys. Lett. 4, 9, 973-977, https://doi.org/10.1209/0295-5075/4/9/004, 1987.

Efron, B.: Nonparametric estimates of standard error: The jackknife, the bootstrap and other methods. Biometrika, 68 (3), 589-599. 1981.

Efron, B., and Tibshirani, R.,: Bootstrap methods for standard errors, confidence intervals, and other measures of statistical accuracy. Stat. Sci., 1 (1), 54-75, 1986.

630 Elderfield, H., Ferretti, P., Greaves, M., Crowhurst, S., McCave, I. N., Hodell, D., and Piotrowski, A. M.: Evolution of Ocean Temperature and Ice Volume Through the Mid-Pleistocene Climate Transition, Science, 337, 704-709, doi:10.1126/science.1221294, 2012.

Emiliani, C.: Pleistocene temperatures, J. Geol., 63, 538-578, 1955.

Fischer, H., Schuepbach, S., Gfeller, G., Bigler, M., Roethlisberger, R., Erhardt, T., Stocker, T. F., Mulvaney,

635 R., and Wolff, E.: Millennial changes in North American wildfire and soil activity over the last glacial cycle, Nat. Geosci., 8, 723-728, https://doi.org/10.1038/ngeo2495, 2015.

Fleitmann, D., Cheng, H., Badertscher, S., Edwards, R. L., Mudelsee, M., Goektuerk, O. M., Fankhauser, A., Pickering, R., Raible, C. C., Matter, A., Kramers, J., and Tuysuz, O.: Timing and climatic impact of Greenland interstadials recorded in stalagmites from northern Turkey, Geophys. Res. Lett., 36, https://doi.org/10.1029/2009gl040050, 2009.

Fletcher, W. J., Goni, M. F. S., Allen, J. R. M., Cheddadi, R., Combourieu-Nebout, N., Huntley, B., Lawson, I., Londeix, L., Magri, D., Margari, V., Mueller, U. C., Naughton, F., Novenko, E., Roucoux, K., and Tzedakis, P. C.: Millennial-scale variability during the last glacial in vegetation records from Europe, Quat. Sci. Rev., 29, 2839-2864, https://doi.org/10.1016/j.quascirev.2009.11.015, 2010. 
Flint, R. F:,. Glacial and Quaternary Geology, J. Wiley, New York, USA. 1971.

Ganopolski, A. and Rahmstorf, S.: Rapid changes of glacial climate simulated in a coupled climate model, Nature, 409, 153-158, 2001.

Genty, D., Blamart, D., Ouahdi, R., Gilmour, M., Baker, A., Jouzel, J., and Van-Exter, S.: Precise dating of Dansgaard-Oeschger climate oscillations in western Europe from stalagmite data, Nature, 421, 833-837, 6502003.

Ghil, M.: Cryothermodynamics: The chaotic dynamics of paleoclimate, Physica D, 77, 130-159, doi: 10.1016/0167-2789(94)90131-7, 1994.

Ghil, M.: Orbital insolation variations, intrinsic climate variability, and Quaternary glaciations, in One Hundred Years of Milanković's Theory of Climate Change, Proceedings of the Workshop Honoring the Milutin Milanković Jubilee, edited by Maksimović, S., Milutin Milanković Association, Belgrade, Serbia, in press, 2021

Ghil, M. and Childress, S. (Eds): Topics in Geophysical Fluid Dynamics: Atmospheric Dynamics, Dynamo Theory and Clim. Dyn., Springer-Verlag, New-York, USA, 1987; reissued as an eBook, 2012.

Ghil, M., and Le Treut, H.: A climate model with cryodynamics and geodynamics, J. Geophys. Res., 86, 52625270, 1981.

Ghil, M., and Lucarini, V., The physics of climate variability and climate change, Rev. Mod. Phys., 92, 035002 , doi: 10.1103/RevModPhys.92.035002, 2020.

Ghil, M., and Tavantzis, J.: Global Hopf Bifurcation in a simple climate model, SIAM J. Appl. Math., 43, 10191041, doi: 10.1137/0143067, 1983.

665 Guillevic, M., Bazin, L., Landais, A., Stowasser, C., Masson-Delmotte, V., Blunier, T., Eynaud, F., Falourd, S., Michel, E., Minster, B., Popp, T., Prie, F., and Vinther, M.: Evidence for a three-phase sequence during Heinrich Stadial 4 using a multiproxy approach based on Greenland ice core records, Clim. Past, 10, 21152133, https://doi.org/10.5194/cp-10-2115-2014, 2014.

Hays, J. D., Imbrie, J., and Shackleton, N. J.: Variations in the Earth's Orbit: Pacemaker of the Ice Ages. Science, 194, 1121-1132, 1976.

Heinrich, H.: Origin and Consequences of Cyclic Ice Rafting in the Northeast Atlantic Ocean during the Past 130,000 years, Quat. Res., 29, 142-152, 1988.

Hemming, S. R.: Heinrich events: Massive late Pleistocene detritus layers of the North Atlantic and their global climate imprint. Rev. Geophys., 42, doi:10.1029/2003RG000128, 2004.

675 Henry, L. G., McManus, J. F., Curry, W. B., Roberts, N. L., Piotrowski, A. M., and Keigwin, L. D.: North Atlantic ocean circulation and abrupt climate change during the last glaciation, Science, 353, 470-474, https://doi.org/10.1126/science.aaf5529, 2016.

Hodell, D. A. and Channell, J. E. T.: Mode transitions in Northern Hemisphere glaciation: co-evolution of millennial and orbital variability in Quaternary climate, Clim. Past, 12, 1805-1828, https://doi.org/10.5194/cp12-1805-2016, 2016

Hoffman, P. F., Abbot, D. S., Ashkenazy, Y., Benn, D. I., Brocks, J. J., Cohen, P. A., Cox, G. M., Creveling, J. R., Donnadieu, Y., Erwin, D. H., Fairchild, I. J., Ferreira, D., Goodman, J. C., Halverson, G. P., Jansen, M. F., Le Hir, G., Love, G. D., Macdonald, F. A., Maloof, A. C., Partin, C. A., Ramstein, G., Rose, B. E. J., Rose, 

USA, 1986.

Jakob, K. A., Wilson, P. A., Pross, J., Ezard, T. H. G., Fiebig, J., Repschlager, J., and Friedrich, O.: A new sealevel record for the Neogene/Quaternary boundary reveals transition to a more stable East Antarctic Ice Sheet, Proc. Natl. Acad. Sci. U. S. A., 117, 30980-30987, https://doi.org/10.1073/pnas.2004209117, 2020.

Johnsen, S. J., Dansgaard, W., Clausen, H. B., and Langway, C. C.: Oxygen isotope profiles through the Antartic and Greenland ice sheets. Nature, 235, 429-434, 1972.

Johnsen, S. J., Dahl-Jensen, D., Gundestrup, N., Steffensen, J. P., Clausen, H. B., Miller, H., MassonDelmotte, V., Sveinbjörnsdottir, A. E., and White, J.: Oxygen isotope and palaeotemperature records from six Greenland ice-core stations: Camp Century, Dye-3, GRIP, GISP2, Renland and NorthGRIP, J. Quat. Sci., 16, 299-307, 2001.

Källén, E., C. Crafoord and M. Ghil,: Free oscillations in a climate model with ice-sheet dynamics, J. Atmos. Sci., 36, 2292-2303, doi: 10.1175/1520-0469(1979)036<2292:FOIACM>2.0.CO;2., 1979.

Kent, D. V., Olsen, P. E., and Muttoni, G.: Astrochronostratigraphic polarity time scale (APTS) for the Late $700 \quad$ Triassic and Early Jurassic from continental sediments and correlation with standard marine stages, EarthSci. Rev., 166, 153-180, https://doi.org/10.1016/j.earscirev.2016.12.014, 2017.

Kent, D. V., Olsen, P. E., Rasmussen, C., Lepre, C., Mundil, R., Irmis, R. B., Gehrels, G. E., Giesler, D., Geissman, J. W., and Parker, W. G.: Empirical evidence for stability of the 405-kiloyear Jupiter-Venus eccentricity cycle over hundreds of millions of years, Proc. Natl. Acad. Sci. U. S. A., 115, 6153-6158, https://doi.org/10.1073/pnas.1800891115, 2018.

Kindler, P., Guillevic, M., Baumgartner, M., Schwander, J., Landais, A., and Leuenberger, M.: Temperature reconstruction from 10 to $120 \mathrm{kyr}$ b2k from the NGRIP ice core, Clim. Past, 10, 887-902, https://doi.org/10.5194/cp-10-887-2014, 2014.

Knudsen, M. F., Norgaard, J., Grischott, R., Kober, F., Egholm, D. L., Hansen, T. M., and Jansen, J. D.: New 710 cosmogenic nuclide burial-dating model indicates onset of major glaciations in the Alps during Middle Pleistocene Transition, Earth Planet. Sci. Lett., 549, https://doi.org/10.1016/j.epsl.2020.116491, 2020.

Kukla, G., McManus, J. F., Rousseau, D.-D., and Chuine, I.: How long and how stable was the last interglacial? Quat. Sci. Rev., 16, 605-612, 1997.

Laskar, J., Fienga, A., Gastineau, M., and Manche, H.: La2010: a new orbital solution for the long-term motion of the Earth, Astron. Astrophys., 532, https://doi.org/10.1051/0004-6361/201116836, 2011.

Le Treut, H., and Ghil, M.: Orbital forcing, climatic interactions, and glaciation cycles, J. Geophys. Res., 88C, 5167-5190, 1983.

Le Treut, H., Portes, J., Jouzel, J., and Ghil, M.: Isotopic modeling of climatic oscillations: implications for a comparative study of marine and ice-core records, J. Geophys. Res., 93, 9365-9383, 1988.

720 Le Verrier, U.-J.: Théorie et Tables du Mouvement Apparent du Soleil, Annales de l'Observatoire Impérial de Paris (in French). Vol. 4, 1858. 
Liebrand, D., Lourens, L. J., Hodell, D. A., de Boer, B., van de Wal, R. S. W., and Paelike, H.: Antarctic ice sheet and oceanographic response to eccentricity forcing during the early Miocene, Clim. Past, 7, 869-880, https://doi.org/10.5194/cp-7-869-2011, 2011.

Lisiecki, L. E. and Raymo, M. E.: A Pliocene-Pleistocene stack of 57 globally distributed benthic delta 0-18 records, Paleoceanography, 20, PA1003, doi:10.1029/2004PA001071, 2005.

Lohmann, G., Butzin, M., Eissner, N., Shi, X., and Stepanek, C.: Abrupt Climate and Weather Changes Across Time Scales, Paleoceanogr. Paleoclimatology, 35, https://doi.org/10.1029/2019PA003782, 2020.

Lohmann, J. and Ditlevsen, P. D.: Random and externally controlled occurrences of Dansgaard-Oeschger events, Clim. Past, 14, 609-617, https://doi.org/10.5194/cp-14-609-2018, 2018.

Lohmann, J. and Ditlevsen, P. D.: Objective extraction and analysis of statistical features of DansgaardOeschger events, Clim. Past, 15, 1771-1792, https://doi.org/10.5194/cp-15-1771-2019, 2019.

MacAyeal, D. R.: Binge/Purge oscillations of the Laurentide ice-sheet as a cause of the North-Atlantics Heinrich events, Paleoceanography, 8, 775-784, https://doi.org/10.1029/93pa02200, 1993.

Marcott, S. A., Clark, P. U., Padman, L., Klinkhammer, G. P., Springer, S. R., Liu, Z. Y., Otto-Bliesner, B. L., Carlson, A. E., Ungerer, A., Padman, J., He, F., Cheng, J., and Schmittner, A.: Ice-shelf collapse from subsurface warming as a trigger for Heinrich events, Proc. Natl. Acad. Sci. U. S. A., 108, 13415-13419, https://doi.org/10.1073/pnas.1104772108, 2011.

Marwan, N., Carmen Romano, M., Thiel, M., and Kurths, J.: Recurrence plots for the analysis of complex systems, Phys. Rep.-Rev. Sec. Phys. Lett., 438, 237-329, https://doi.org/10.1016/j.physrep.2006.11.001, 2007.

Marwan, N., Schinkel, S., and Kurths, J.: Recurrence plots 25 years later - Gaining confidence in dynamical transitions, EPL, 101, https://doi.org/10.1209/0295-5075/101/20007, 2013.

McManus, J. F., Bond, G. C., Broecker, W. S., Johnsen, S., Labeyrie, L., and Higgins, S.: High-resolution climate records from the North Atlantic during the last interglacial. Nature, 371, 326-329, 1994.

McManus, J. F., Francois, R., Gherardi, J. M., Keigwin, L. D., and Brown-Leger, S.: Collapse and rapid resumption of Atlantic meridional circulation linked to deglacial climate changes. Nature, 428, 834-837, https://doi.org/10.1038/nature02494, 2004.

McManus, J. F., Oppo, D. W., and Cullen, J. L.: A 0,5-million-year record of millennial-scale climate variability in the North Atlantic, Science, 283, 971-975, 1999.

Menviel, L., Timmermann, A., Friedrich, T., and England, M. H.: Hindcasting the continuum of DansgaardOeschger variability: mechanisms, patterns and timing, Clim. Past, 10, 63-77, https://doi.org/10.5194/cp-1063-2014, 2014.

Menviel, L., Skinner, L. C., Tarasov, L., and Tzedakis, P. C.: An ice-climate oscillatory framework for Dansgaard-Oeschger cycles, Nat. Rev. Earth Env., 1, 677-693, https://doi.org/10.1038/s43017-020-00106y, 2021.

Meyers, S. R. and Malinverno, A.: Proterozoic Milankovitch cycles and the history of the solar system, Proc. Natl. Acad. Sci. U. S. A., 115, 6363-6368, https://doi.org/10.1073/pnas.1717689115, 2018.

Milankovitch, M.: Théorie mathématique des phénomènes thermiques produits par la radiation solaire, Académie Yougoslave des Sciences et des Arts de Zagreb (Ed.), Gauthier Villars, Paris, 1920. 
Milankovitch, M.: Kanon der Erdbestrahlung und seine Anwendung auf das Eiszeitenproblem, Royal Serbian Academy of Sciences, Belgrade, 1941

Miller, G. H., and de Vernal, A.: Will greenhouse warming lead to Northern Hemisphere ice-sheet growth? Nature, 355 (6357), 244-246, 1992.

Miller, K. G., Mountain, G. S., Wright, J. D., and Browning, J. V.: A 180-Million-Year Record of Sea Level and Ice Volume Variations from Continental Margin and Deep-Sea Isotopic Records, Oceanography, 24, 40-53, https://doi.org/10.5670/oceanog.2011.26, 2011.

Müller, U. C., Pross, J., and Bibus, E.: Vegetation response to rapid climate change in Central Europe during the past 140,000 yr based on evidence from the Füramoos pollen record, Quat. Res., 59, 235-245, 2003.

Muttoni, G., Carcano, C., Garzanti, E., Ghielmi, M., Piccin, A., Pini, R., Rogledi, S., and Sciunnach, D.: Onset of major Pleistocene glaciations in the Alps, Geology, 31, 989-992, https://doi.org/10.1130/g19445.1, 2003.

Naafs, B. D. A., Hefter, J., and Stein, R.: Millennial-scale ice rafting events and Hudson Strait Heinrich(-like) Events during the late Pliocene and Pleistocene: a review, Quat. Sci. Rev., 80, 1-28, https://doi.org/10.1016/j.quascirev.2013.08.014, 2013.

Obrochta, S. P., Crowley, T. J., Channell, J. E. T., Hodell, D. A., Baker, P. A., Seki, A., and Yokoyama, Y.: Climate variability and ice-sheet dynamics during the last three glaciations, Earth Planet. Sci. Lett., 406, 198-212, https://doi.org/10.1016/j.epsl.2014.09.004, 2014.

Olsen, P. E., Laskar, J., Kent, D. V., Kinney, S. T., Reynolds, D. J., Sha, J. G., and Whiteside, J. H.: Mapping Solar System chaos with the Geological Orrery, Proc. Natl. Acad. Sci. U. S. A., 116, 10664-10673, https://doi.org/10.1073/pnas.1813901116, 2019.

Penck, A. and Brückner, E.: Die Alpen im Eiszeitalter, 3 vols., C. H. Tauchnitz, Leipzig, Germany, 1909.

Pilgrim, L.: Versuch einer rechnerischen Behandlung der Eiszeit, Jahreshefte des Vereins für Vateri. Naturkunde in Würtemberg, Bd 60, 1904.

Pisias, N. G. and Moore, T. C.: The evolution of Pleistocene climate: A time-series approach, Earth Planet. Sci. Lett., 52, 450-458, https://doi.org/10.1016/0012-821x(81)90197-7, 1981.

Rahmstorf, S.: Ocean circulation and climate during the past 120,000 years, Nature, 419, 207-214, 2002.

Rasmussen, S. O., Bigler, M., Blockley, S. P., Blunier, T., Buchardt, S. L., Clausen, H. B., Cvijanovic, I., DahlJensen, D., Johnsen, S. J., Fischer, H., Gkinis, V., Guillevic, M., Hoek, W. Z., Lowe, J. J., Pedro, J. B., Popp, T., Seierstad, I. K., Steffensen, J. P., Svensson, A. M., Vallelonga, P., Vinther, B. M., Walker, M. J. C., Wheatley, J. J., and Winstrup, M.: A stratigraphic framework for abrupt climatic changes during the Last Glacial period based on three synchronized Greenland ice-core records: refining and extending the INTIMATE event stratigraphy, Quat. Sci. Rev., 106, 14-28, https://doi.org/10.1016/j.quascirev.2014.09.007, 2014.

Riechers, K., Mitsui, T., Boers, N. and Ghil, M. Orbital insolation variations, intrinsic climate variability, and 795 Quaternary glaciations, Clim. Past, submitted, 2021.

Rousseau, D.-D., Antoine, P., Hatté, C., Lang, A., Zöller, L., Fontugne, M., Ben Othman, D., Luck, J. M., Moine, O., Labonne, M., Bentaleb, I., and Jolly, D.: Abrupt millennial climatic changes from Nussloch (Germany) Upper Weichselian eolian records during the Last Glaciation, Quat. Sci. Rev., 21, 1577-1582, 2002.

Rousseau, D.-D., Kukla, G., and McManus, J.: What is what in the ice and the ocean? Quat. Sci. Rev., 25, 2025-2030, 2006. 
Rousseau, D.-D., Boers, N., Sima, A., Svensson, A., Bigler, M., Lagroix, F., Taylor, S., and Antoine, P.: (MIS3 \& 2) millennial oscillations in Greenland dust and Eurasian aeolian records - A paleosol perspective, Quat. Sci. Rev., 169, 99-113, https://doi.org/10.1016/j.quascirev.2017.05.020, 2017a

Rousseau, D.-D., Svensson, A., Bigler, M., Sima, A., Steffensen, J. P., and Boers, N.: Eurasian contribution to the last glacial dust cycle: how are loess sequences built? Clim. Past, 13, https://doi.org/10.5194/cp-131181-2017, 2017b.

Rousseau, D.-D., Antoine, P., and Sun, Y.: How dusty was the last glacial maximum over Europe? Quat. Sci. Rev., 254, 6775-6775, 2021.

Ruddiman, W. F.: Late Quaternary deposition of ice) rafted sand in subpolar North-Atlantic (Lat 40-degrees to 65-degrees-N), Geol. Soc. Am. Bull., 88, 1813-1827, https://doi.org/10.1130/00167606(1977)88<1813:Iqdois>2.0.co;2, 1977.

Ruddiman, W. F., Raymo, M., Martinson, D. G., Clement, B. M., and Backman, J.: Pleistocene evolution: Northern Hemisphere ice sheets and North Atlantic Ocean. Paleoceanography, 4, 353-412, 1989.

Saltzman B.: Dynamical Paleoclimatology. Academic Press, San Diego, USA, 2002.

815 Sanchez-Goni, M. F., Turon, J. L., Eynaud, F., and Gendreau, S.: European climatic response to millennialscale changes in the atmosphere-ocean system during the last glacial period, Quat. Res., 54, 394-403, 2000.

Sanchez-Goni, M. F., Cacho, I., Turon, J. L., Guiot, J., Sierro, F. J., Peypouquet, J. P., Grimalt, J. O., and Shackleton, N. J.: Synchroneity between marine and terrestrial responses to millennial scale climatic variability during the last glacial period in the Mediterranean region, Clim. Dyn., 19, 95-105, https://doi.org/10.1007/s00382-001-0212-x, 2002.

Sarnthein, M., Stattegger, K., Dreger, D., Erlenkeuser, H., Grootes, P., Haupt, B. J., Jung, S., Kiefer, T., Kuhnt, W., Pflaumann, U., Schäfer-Neth, C., Schulz, H., Schulz, M., Seidov, D., Simstich, J., van Kreveld, S., Vogelsang, E., Völker, A., and Weinelt, M.: Fundamental Modes and Abrupt Changes in North Atlantic Circulation and Climate over the last $60 \mathrm{ky}$ - Concepts, Reconstruction and Numerical Modeling, in "The Northern North Atlantic", edited by: Schäfer P., Ritzrau W., Schlüter M., and Thiede J. Springer, 365-410, https://doi.org/10.1007/978-3-642-56876-3_21, 2001.

Schulz, M.: On the 1470-year pacing of Dansgaard-Oeschger warm events, Paleoceanography, 17, 4.1-4.10, 2002.

Schupbach, S., Fischer, H., Bigler, M., Erhardt, T., Gfeller, G., Leuenberger, D., Mini, O., Mulvaney, R., Abram, N. J., Fleet, L., Frey, M. M., Thomas, E., Svensson, A., Dahl-Jensen, D., Kettner, E., Kjaer, H., Seierstad, I., Steffensen, J. P., Rasmussen, S. O., Vallelonga, P., Winstrup, M., Wegner, A., Twarloh, B., Wolff, K., Schmidt, K., Goto-Azuma, K., Kuramoto, T., Hirabayashi, M., Uetake, J., Zheng, J., Bourgeois, J., Fisher, D., Zhiheng, D., Xiao, C., Legrand, M., Spolaor, A., Gabrieli, J., Barbante, C., Kang, J. H., Hur, S. D., Hong, S. B., Hwang, H. J., Hong, S., Hansson, M., lizuka, Y., Oyabu, I., Muscheler, R., Adolphi, F., Maselli, O., McConnell, J., and Wolff, E. W.: Greenland records of aerosol source and atmospheric lifetime changes from the Eemian to the Holocene, Nat. Commun., 9, https://doi.org/10.1038/s41467-018-03924-3, 2018.

Scotese, C. R., Song, H., Mills, B. J. W., and van der Meer, D. G.: Phanerozoic paleotemperatures: The Earth's changing climate during the last 540 million years, Earth-Sci. Rev., 215, 
Seki, O., Foster, G. L., Schmidt, D. N., Mackensen, A., Kawamura, K., and Pancost, R. D.: Alkenone and boron-based Pliocene $\mathrm{pCO}_{2}$ records, Earth Planet. Sci. Lett., 292, 201-211, https://doi.org/10.1016/j.epsl.2010.01.037, 2010.

Sellers, W. D.: A global climatic model based on the energy balance of the earth-atmosphere system. J. Appl. Meteorol., 8, 392-400, 1969.

Shackleton, N. J.: The 100,000-year Ice-age cycle identified and found to lag temperature, carbon dioxide, and orbital eccentricity. Science 289, 1897-1902, 2000.

Shackleton, N. J. and Opdyke, N. D.: Oxygen isotope and palaeomagnetic evidence for early Northern Hemisphere glaciation. Nature, 270, 216-223, 1977.

Stocker, T. F. and Johnsen, S. J.: A minimum thermodynamic model for the bipolar seesaw, Paleoceanography, 18, 11-1-11-9, 2003.

Svensson, A., Dahl-Jensen, D., Steffensen, J. P., Blunier, T., Rasmussen, S. O., Vinther, B. M., Vallelonga, P., Capron, E., Gkinis, V., Cook, E., Kjaer, H. A., Muscheler, R., Kipfstuhl, S., Wilhelms, F., Stocker, T. F., Fischer, H., Adolphi, F., Erhardt, T., Sigl, M., Landais, A., Parrenin, F., Buizert, C., McConnell, J. R., Severi, M., Mulvaney, R., and Bigler, M.: Bipolar volcanic synchronization of abrupt climate change in Greenland and Antarctic ice cores during the last glacial period, Clim. Past, 16, 1565-1580, https://doi.org/10.5194/cp16-1565-2020, 2020.

Turner, S. K.: Pliocene switch in orbital-scale carbon cycle/climate dynamics, Paleoceanography, 29, 12561266, https://doi.org/10.1002/2014pa002651, 2014.

Tziperman, E. and Gildor, H.: On the mid-Pleistocene transition to 100-kyr glacial cycles and the asymmetry between glaciation and deglaciation times, Paleoceanography, 18(1), 1001, doi:10.1029/2001PA000627, 2003.

Waelbroeck, C., Labeyrie, L., Michel, E., Duplessy, J. C., McManus, J. F., Lambeck, K., Balbon, E., and Labracherie, M.: Sea-level and deep water temperatures changes derived from benthic foraminifera isotopic records, Quat. Sci. Rev., 21, 295-305, 2002.

van de Wal, R. S. W., de Boer, B., Lourens, L. J., Koehler, P., and Bintanja, R.: Reconstruction of a continuous high-resolution $\mathrm{CO} 2$ record over the past 20 million years, Clim. Past, 7, 1459-1469, https://doi.org/10.5194/cp-7-1459-2011, 2011.

Wang, Y. J., Cheng, H., Edwards, R. L., An, Z. S., Wu, J. Y., Shen, C. C., and Dorale, J. A.: A high-resolution absolute-dated Late Pleistocene monsoon record from Hulu Cave, China, Science, 294, 2345-2348, https://doi.org/10.1126/science.1064618, 2001.

Westerhold, T., Marwan, N., Drury, A. J., Liebrand, D., Agnini, C., Anagnostou, E., Barnet, J. S. K., Bohaty, S. M., De Vleeschouwer, D., Florindo, F., Frederichs, T., Hodell, D. A., Holbourn, A. E., Kroon, D., Lauretano, V., Littler, K., Lourens, L. J., Lyle, M., Palike, H., Rohl, U., Tian, J., Wilkens, R. H., Wilson, P. A., and

875 Zachos, J. C.: An astronomically dated record of Earth's climate and its predictability over the last 66 million years, Science, 369, 1383-1387, https://doi.org/10.1126/science.aba6853, 2020.

Woillard, G.: Grande Pile Peat Bog : A Continuous Pollen Record for the Last 140,000 Years, Quat. Res. 9, 1-21, 1978. 
https://doi.org/10.5194/cp-2021-103

Preprint. Discussion started: 11 August 2021

(c) Author(s) 2021. CC BY 4.0 License.

Wolff, E. W., Chappellaz, J., Blunier, T., Rasmussen, S. O., and Svensson, A.: Millennial-scale variability during the last glacial: The ice core record, Quat. Sci. Rev., 29, 2828-2838, https://doi.org/10.1016/j.quascirev.2009.10.013, 2010.

Zachos, J., Pagani, M., Sloan, L., Thomas, E., and Billups, K.: Trends, rhythms, and aberrations in global climate 65 Ma to present, Science, 292, 686-693, 2001.

Zagwijn, W. H.: Vegetation and climate during warmer intervals in the Late Pleistocene of western and central

$885 \quad$ Europe, Quat. Int., 3/4, 57-67, 1989.

Zhang, S., Wang, X., Hammarlund, E. U., Wang, H., Costa, M. M., Bjerrum, C. J., Connelly, J. N., Zhang, B., Bian, L., and Canfield, D. E.: Orbital forcing of climate 1.4 billion years ago, Proc. Natl. Acad. Sci. U. S. A., 112, E1406-E1413, https://doi.org/10.1073/pnas.1502239112, 2015.

Ziemen, F. A., Kapsch, M.-L., Klockmann, M., and Mikolajewicz, U.: Heinrich events show two-stage climate 890 response in transient glacial simulations, Clim. Past, 15, 153-168, https://doi.org/10.5194/cp-15-153-2019, 2019. 


\section{Figure captions}

895 Figure 1. Earth Climate history represented by two marine records and an ice core one. (a) Record of benthic $\delta^{18} \mathrm{O}$ of the CENOGRID stack for the last $66 \mathrm{Myr}$; the hot, warm, cool, and icehouse intervals, after Westerhold et al. (2020), are indicated along the abscissa. (b) Benthic $\delta^{18} \mathrm{O}$ record of the U1308 marine core (Hodell and Channell, 2016) for the last $3.2 \mathrm{Myr}$; the $40 \mathrm{kyr}, 100 \mathrm{kyr}$, and Mid-Pleistocene transition (MPT) intervals are indicated along the top of the diagram. (c) $122 \mathrm{ka} b 2 \mathrm{k} \delta^{18} \mathrm{O}$ of the NGRIP ice core (Rasmussen et al., 2014) for the last 122 kyr b2k. Here 'b2k' means before 2000 A.D.

Figure 2. Recurrence analysis of the $\delta^{18} \mathrm{O}$ record in U1308 Cibicioides sp. (a) Recurrence plot (RP); the proximity threshold is $\Delta\left(\delta^{18} \mathrm{O}\right)=0.2$ per mil. (b) Time series of the Cibicidoides sp. $\delta^{18} \mathrm{O}$ (blue curve, top) and of the bulk carbonate $\delta^{18} \mathrm{O}$ (magenta curve, bottom); [l suggest changing the green to a color that has more contrast wrt the blue.] from Hodell and Channell (2016). Vertical bars represent the five thresholds determined by the analysis. The RP web site is http://www.recurrence-plot.tk/.

Figure 3. Recurrence analysis of $\mathrm{U} 1308$ bulk carbonate $\delta^{18} \mathrm{O}$. (a) RP of the bulk carbonate $\delta^{18} \mathrm{O}$, with the same proximity threshold as in fig. $2 \mathrm{~A}$. (b) same as fig. $2 \mathrm{~B}$, except that the vertical bars now represent the seven

910 thresholds determined by the analysis of the time series in fig. 3a. The RP web site is http://www.recurrenceplot.tk/.

Figure 4. Recurrence analysis of NGRIP $\delta^{18} \mathrm{O}$. (a) NGRIP $\delta^{18} \mathrm{O}$ variations over the last $122 \mathrm{kyr}$ b2k (Rasmussen et al., 2014); selected canonical Dansgaard-Oeschger (DO) events are indicated on the abscissa by the

915 numbers assigned by Dansgaard et al. (1993). (b) RP of the time series in panel (A) above; the proximity threshold here is $\Delta\left(\delta^{18} \mathrm{O}\right)=1.3$ per mil). (c) Variation of the sea level over the last $122 \mathrm{kyr} B P$, as reconstructed from benthic $\delta^{18} \mathrm{O}$ foraminifera by Waelbroeck et al. (2002); bold red line is the global mean sea level $(\mathrm{m})$ below present, and light blue lines are the minimum and maximum global mean sea level values $(\mathrm{m})$ below present. Horizontal green line segmentd indicate some key sea levels. The RP web site is http://www.recurrence-plot.tk/.

Figure 5. Variations in the percentage of Neogloboquadrina pachyderma (s.), a species indicative of cold surface water, from DSDP 609 (Bond et al., 1992), illustrating two Bond cycles. These cycles show a series of Dansgaard-Oeschger (DO) cycles composed of an abrupt warming that is followed by a return to glacial conditions represented by "stadials." Every Bond cycle corresponds to a long-term cooling trend that starts with a strong warming and ends with a stadial that includes a massive iceberg discharge into the North Atlantic; the latter Heinrich events (HEs) are marked by a letter 'H', followed by a number assigned by Bond et al. (1992)).

Figure 6. Schematic diagram of the proposed, updated Bond cycle. (a) The amended scheme here differs from

930 the one in fig. 5 by using the NGRIP $\delta^{18} \mathrm{O}$ data of Rasmussen et al. (2014) to mark the Greenland stadials (GSs) and interstadials (GIs). A DO event consists of a very short GI, followed by a longer GS. IRD events 
https://doi.org/10.5194/cp-2021-103

Preprint. Discussion started: 11 August 2021

(c) Author(s) 2021. CC BY 4.0 License.

(c) (1)

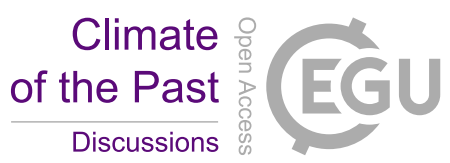

observed in contemporaneous marine records by Bond and Lotti (1995), are indicated by the letters ' $f$ ' to " $h$ " while IRD events that were observed but not assigned a number also by Bond and Lotti (1995), are indicated by a letter ' $\mathrm{X}$ '. HE numbers as in fig. 5. (b) Maps illustrating the climate evolution associated with the "Long-Term

935 Cooling Trend" that corresponds to a Bond cycle in panel (A) above; the last DO cycle, named a Heinrich Stadial, is characterized by a massive release of icebergs. Annual mean SST $\left({ }^{\circ} \mathrm{C}\right.$ ) for a GI (here $47 \mathrm{ka}$ ), a GS (here $44.4 \mathrm{ka}$ ), and a Heinrich stadial (here $48 \mathrm{ka}$ ), as simulated in a transient experiment of MIS3 (Menviel et al., 2014, 2021). GIS = Greenland Ice Sheet, LIS = Laurentide Ice Sheet, BIS = British Isles Ice Sheet, and FIS = Fenno-Scandian Ice Sheet.

940

Table captions

Table 1. Comparison of the main steps detected by Hodell and Channell (2016) from U1308 marine record with those deduced from the Recurrence Plot of the benthic $\delta^{18} \mathrm{O}$ and bulk carbonate $\delta^{18} \mathrm{O}$ data of the same record.

945 Table 2. Thresholds identified in the recurrence plot of NGRIP $\delta^{18} \mathrm{O}$ record and their correspondence in the marine isotope stratigraphy of the last climate cycle stratigraphy (Bassinot et al., 1994; McManus et al., 1994; Kukla et al., 1997; Lisiecki and Raymo, 2005; Clark et al., 2009). MIS: Marine Isotope Stage, Marine C event: Marine Cold event, LGM: Last Glacial Maximum. Two dates are proposed for the onset of MIS1: * according to Bassinot et al., 1994, \$ according to Lisiecki and Raymo, 2005 

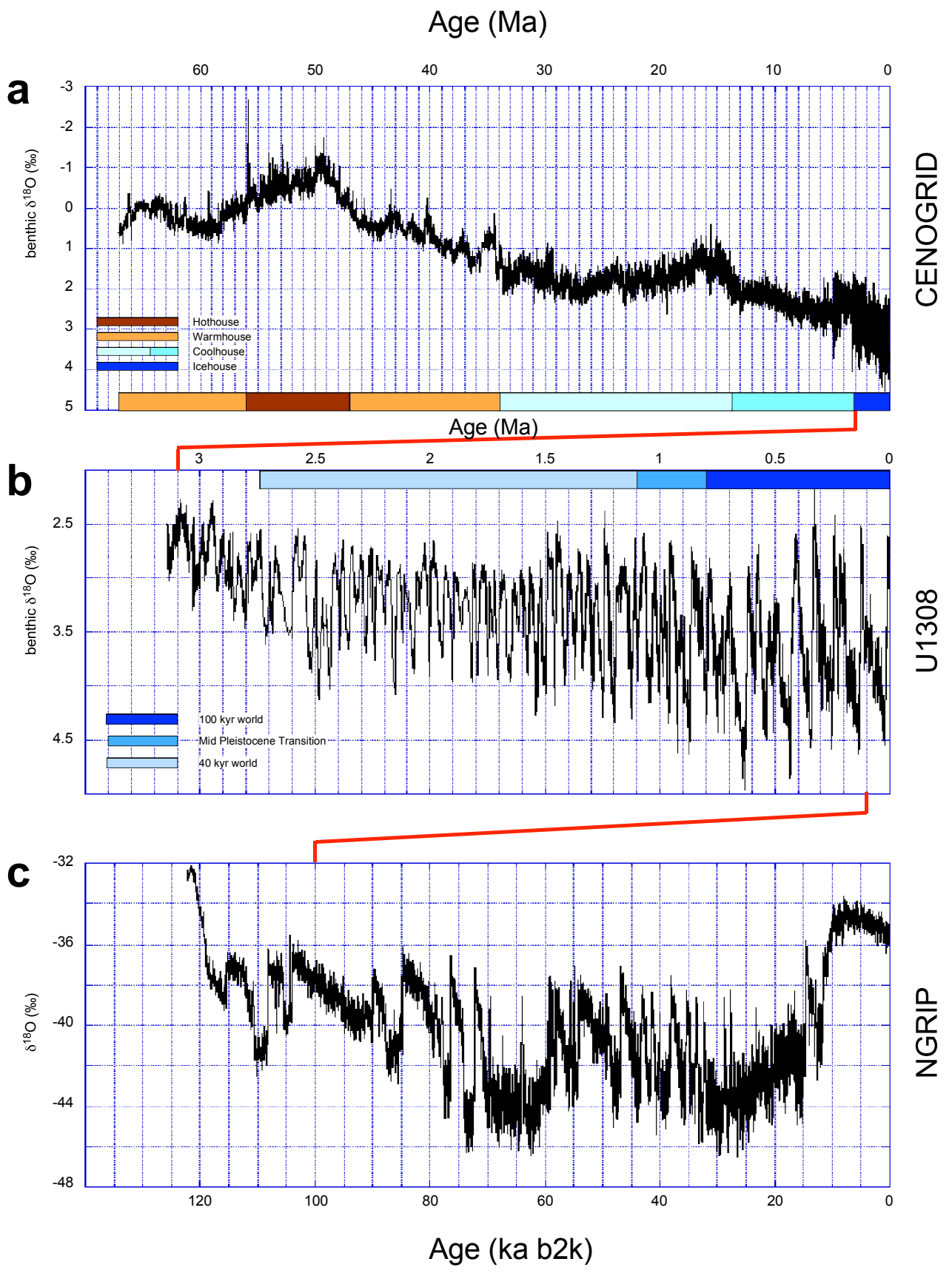

Fig. 1 
https://doi.org/10.5194/cp-2021-103

Preprint. Discussion started: 11 August 2021

(c) Author(s) 2021. CC BY 4.0 License.

\section{Climate of the Past \\ Discussions} (c) (1)

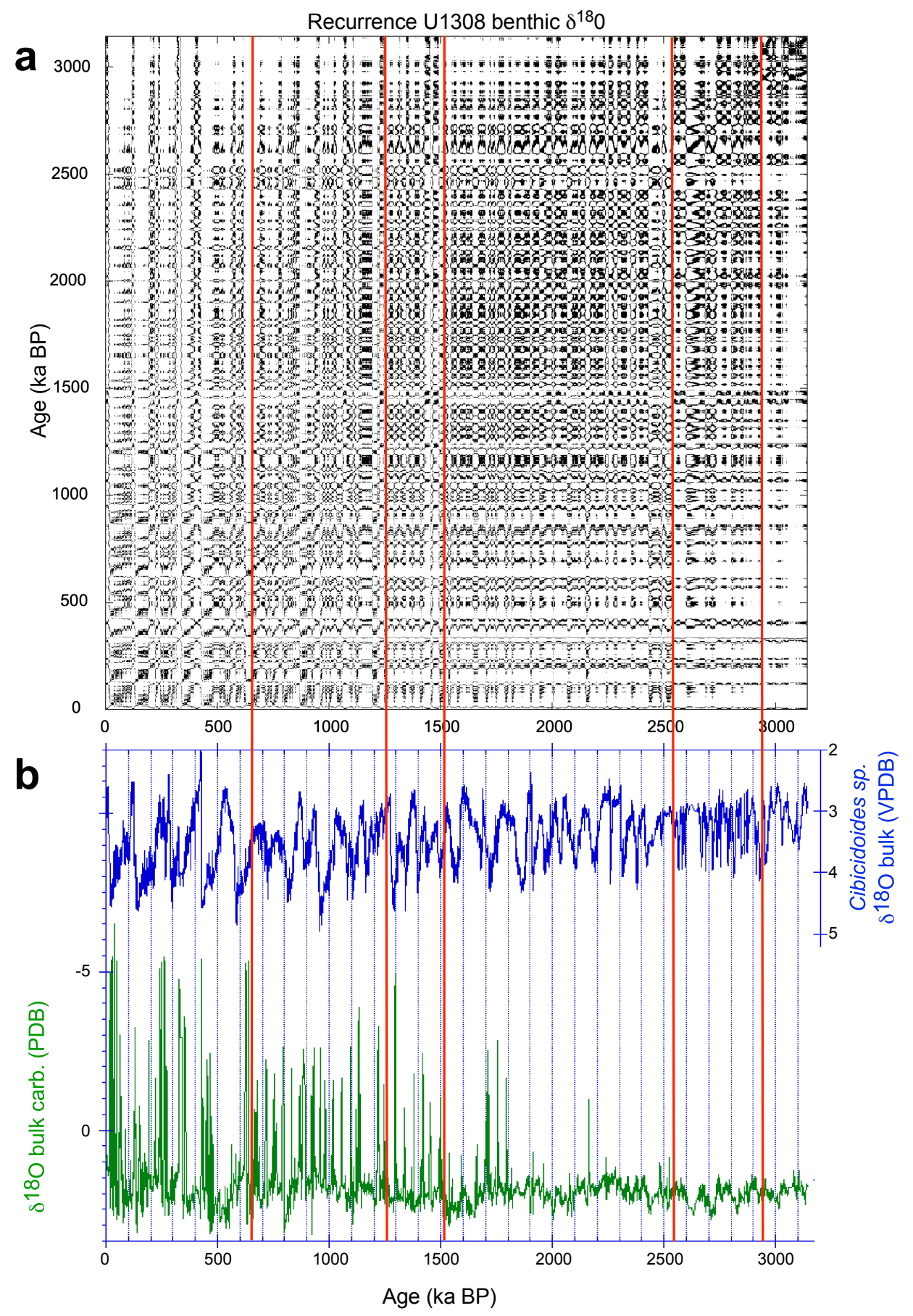

Fig. 2 
https://doi.org/10.5194/cp-2021-103

Climate

Preprint. Discussion started: 11 August 2021

(c) Author(s) 2021. CC BY 4.0 License.

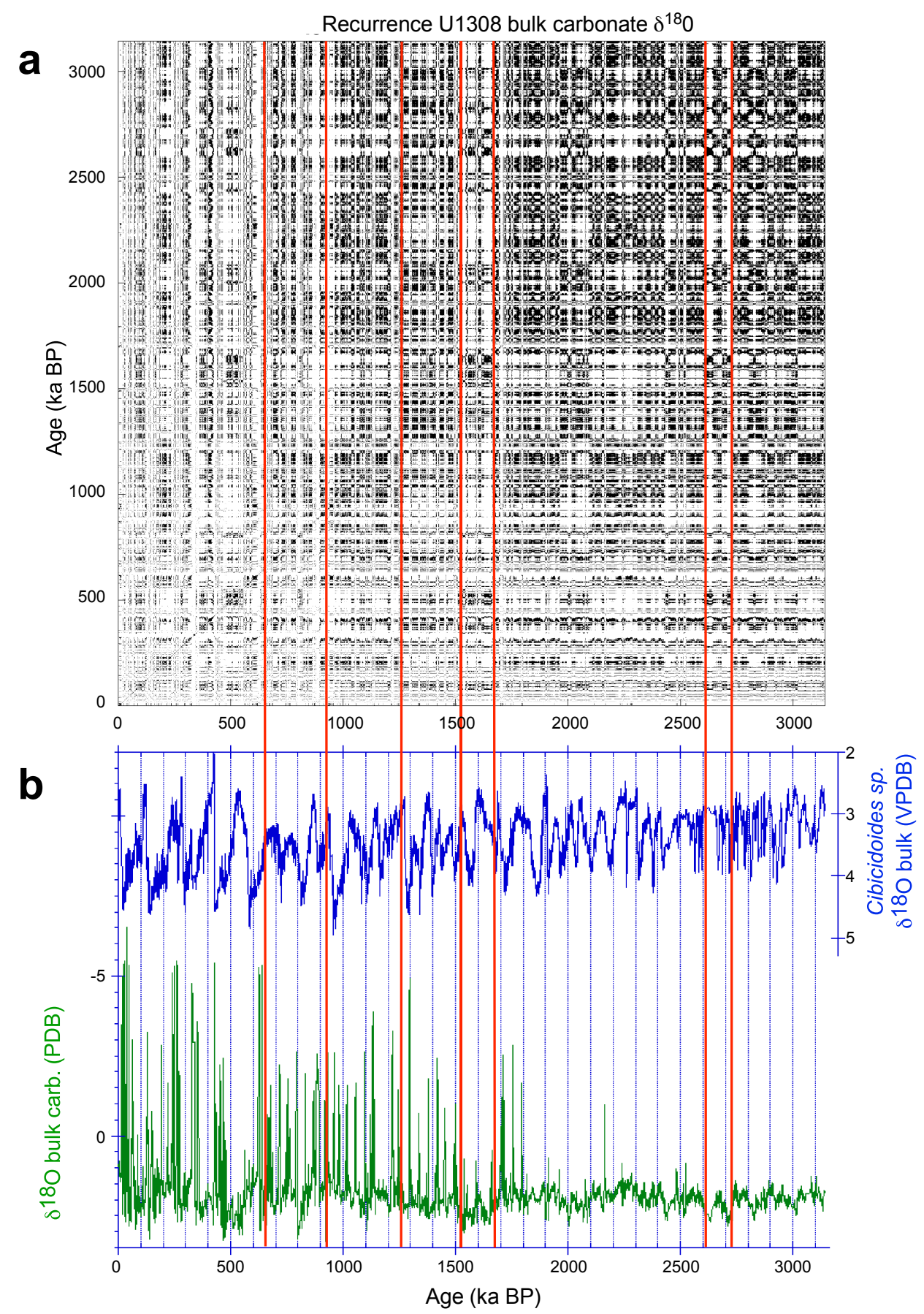


https://doi.org/10.5194/cp-2021-103

Preprint. Discussion started: 11 August 2021

(c) Author(s) 2021. CC BY 4.0 License.

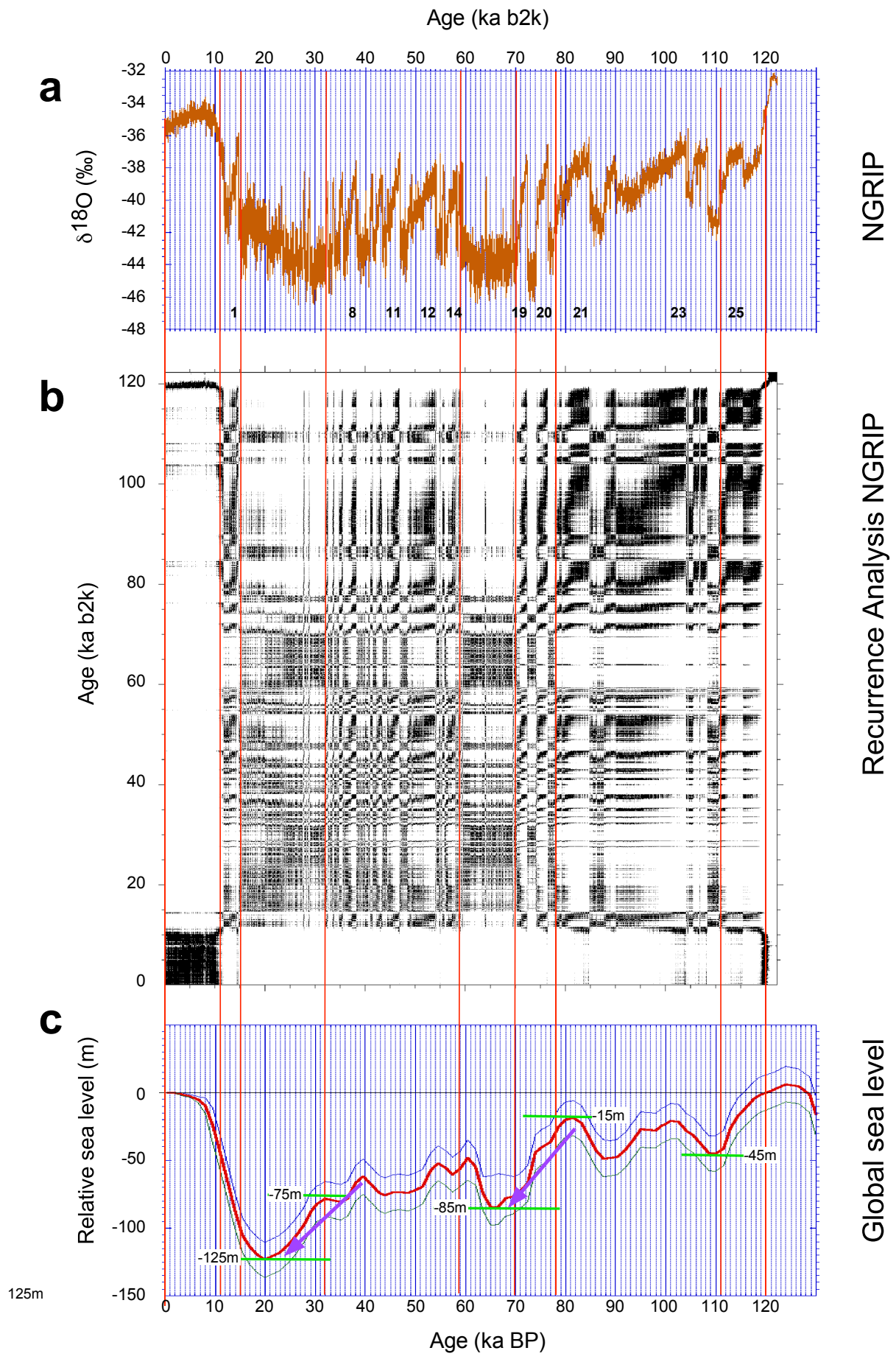

Fig. 4 


\section{Age (ka BP)}

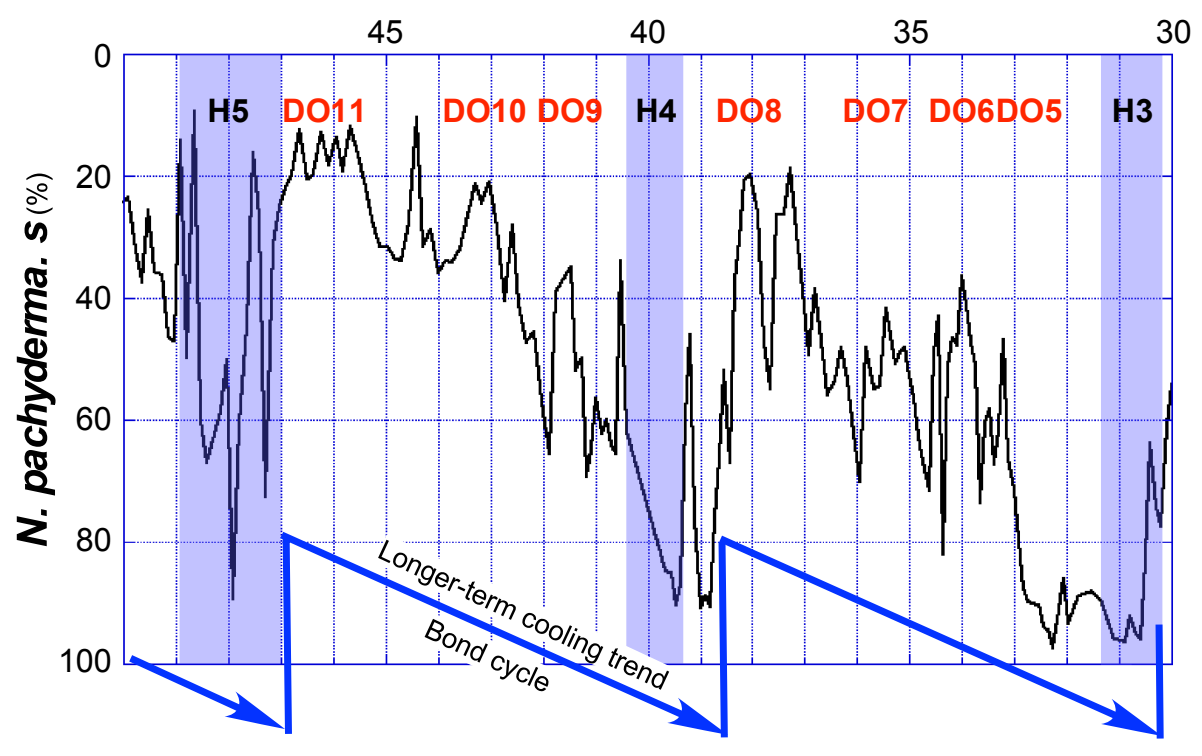


https://doi.org/10.5194/cp-2021-103

Preprint. Discussion started: 11 August 2021

(c) Author(s) 2021. CC BY 4.0 License.

a

Age (ka b2k)
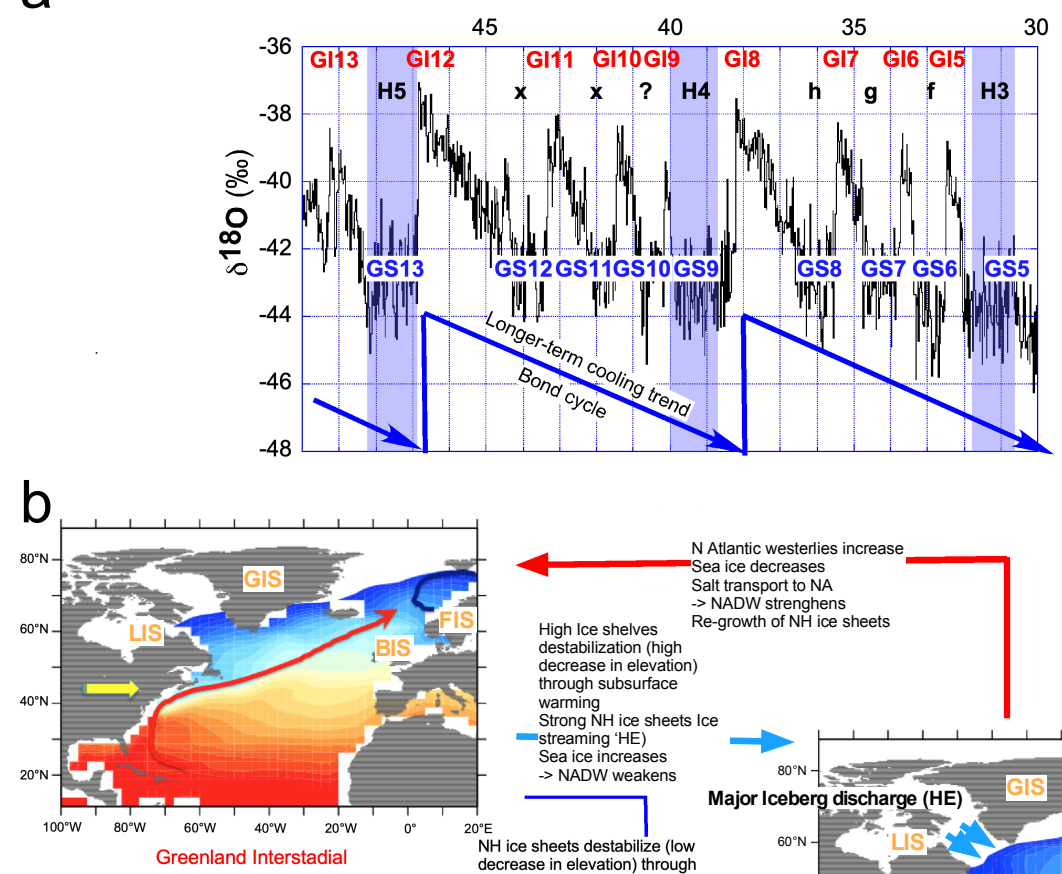

N Atlantic westerlies increase

$N$ Atlantic westerlies
Sea ice decreases

Salt transport to NA

Re-growth of NH ice sheets

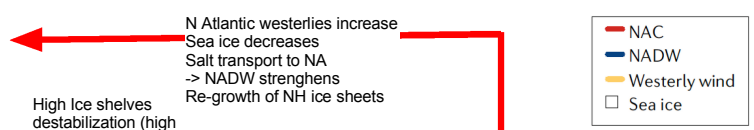

n (high

decrease in elevation)
through subsurface

warming

streaming ice sheets Ice

Sea ice increases

$\rightarrow$ NADW weakens
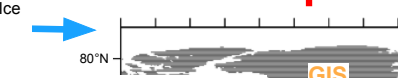

ice sheets destabilize (low decrease in elevation) through subsurface warming Ice streaming increases Sea ice increases (IRDs)
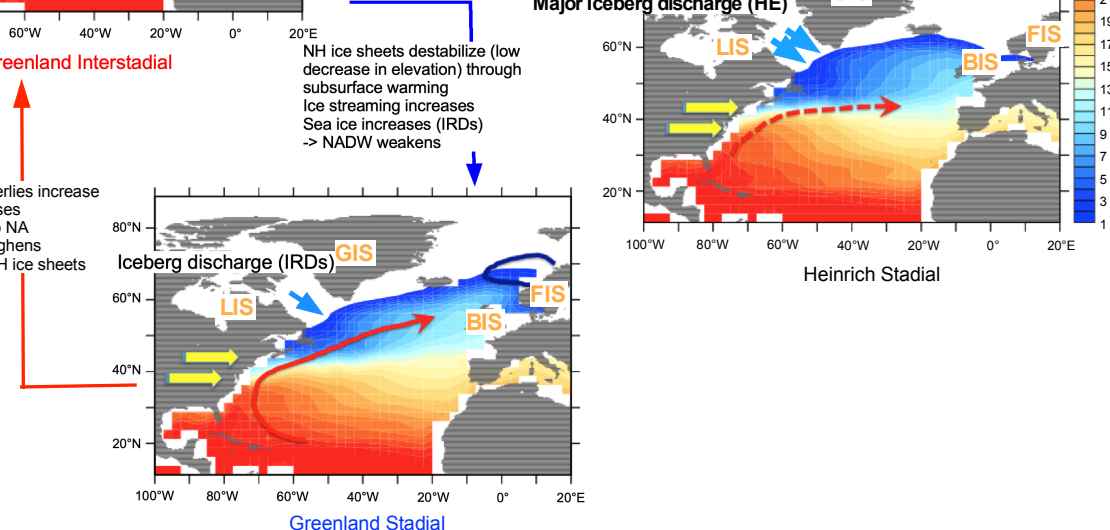

Fig. 6 
https://doi.org/10.5194/cp-2021-103

Preprint. Discussion started: 11 August 2021

(c) Author(s) 2021. CC BY 4.0 License.

\begin{tabular}{c} 
Climate \\
of the Past \\
\hline Discussions
\end{tabular}

965

Tab. 1

\begin{tabular}{ccc}
\hline $\begin{array}{c}\text { Hodell \& Channell (2016) } \\
\text { main steps in Ma }\end{array}$ & $\begin{array}{c}\text { Benthic } \delta^{18} 0 \\
\text { thresholds in Ma }\end{array}$ & $\begin{array}{c}\text { Bulk Carbonate } \delta^{18} 0 \\
\text { thresholds in Ma }\end{array}$ \\
\hline \multirow{2}{*}{2.75} & 2.95 & 2.75 \\
& & \\
1.5 & 2.55 & 1.5 \\
& 1.5 & 1.25 \\
0.9 & 1.25 & 0.9 \\
0.65 & 0.65 & 0.65 \\
\hline
\end{tabular}


https://doi.org/10.5194/cp-2021-103

Preprint. Discussion started: 11 August 2021

(c) Author(s) 2021. CC BY 4.0 License.

\begin{tabular}{c} 
Climate \\
of the Past \\
\hline Discussions
\end{tabular}

$970 \quad$ Tab. 2

\begin{tabular}{cc}
\hline $\begin{array}{c}\text { NGRIP } \delta^{18} 0 \\
\text { thresholds in ka (b2k) }\end{array}$ & Marine Isotope Stratigraphy \\
\hline 11 & onset of MIS1 ${ }^{\$}$ \\
15 & onset of MIS1 \\
32 & onset Last LGM \\
59 & onset MIS3 \\
69 & onset MIS4 \\
& peak marine substage 5.1 - marine \\
78 & event C20 \\
111 & peak marine substage 5.4 - marine \\
\end{tabular}

